\title{
STREDOVEKÉ ZAHĹBENÉ KUPOLOVÉ PECE Z PONITRIA ${ }^{1}$
}

\author{
Medieval Recessed Cupola Ovens from the Nitra Region
}

\author{
Dominik Repka - Noémi Beljak Pažinová
}

DOI: 10.17846/CL.2018.11.1.16-39

\begin{abstract}
REPKA, Dominik - BELJAK PAŽINOVÁ, Noémi. Medieval Recessed Cupola Ovens from the Nitra Region. The contribution seeks to present the newest finds of recessed medieval cupola ovens in Nitra region. The finds were excavated by the Department of Archaeology at the Constantine the Philosopher University in Nitra. The paper provides a detailed analysis of a system of three connected recessed cupola ovens from Nitra, Dolné Krškany and a recessed single-chamber cupola oven with entry steps from Svätoplukovo. The material from this locality dates back to the second half of the 11th until the beginning of the 13th century. In Slovakia, their concentration is significant predominantly in the Nitra region; therefore, the paper attempts to evaluate these ovens in the context of analogous finds known from other medieval settlements in the region. In conclusion, the contribution also interprets their possible function and usage.
\end{abstract}

Keywords: Nitra region, cupola ovens, Middle Ages, Dolné Krškany, Svätoplukovo, oven types, function

\begin{abstract}
Abstrakt: REPKA, Dominik - BELJAK PAŽINOVÁ, Noémi. Stredoveké zahlibené kupolové pece $z$ Ponitria. Cielom príspevku je prezentácia najnovších nálezov zahĺbených kupolových pecí na území Ponitria $\mathrm{z}$ obdobia začiatku vrcholného stredoveku, zistených a preskúmaných Katedrou archeológie FF Univerzity Konštantína Filozofa v Nitre. Podrobne predstavená a analyzovaná bude prepojená sústava troch zahĺbených kupolových pecí z Nitry, čast Dolné Krškany a jednokomorová zahĺbená kupolová pec so schodovitou úpravou predpecnej jamy v Svätoplukove. Nálezový materiál z týchto lokalít poukazuje na datovanie do druhej polovice 11. storočia až začiatku 13. storočia. Kedže na Slovensku je koncentrácia týchto objektov výrazná práve na území Ponitria, je našou snahou vyhodnotit objavené pece v kontexte $\mathrm{s}$ analogickými celkami známymi z dalších sídlisk z regiónu. Na záver sa pokúsime aj o interpretáciu ich možnej funkcie a spôsobu využitia.
\end{abstract}

Klúčové slová: Ponitrie, kupolové pece, stredovek, Dolné Krškany, Svätoplukovo, typy pecí, funkcia

\section{Úvod}

Pece patria nielen v období stredoveku medzi dôležité nálezy, pretože sú svedectvom hospodárskej, ako aj výrobnej činnosti našich predkov. V minulosti sa ich typológiou, konštrukciou a funkciou

Príspevok vznikol v rámci riešenia projektu VEGA 1/0208/15 Človek a hory v priebehu času - od pravekých hradísk $k$ stredovekým hradom. 
zaoberalo viacero bádatel’ov, nielen u nás, resp. v bývalom Československu (napr. Čaplovič 1987; Daňo 1995; Langer 1987; Ruttkay 1990; 2002a, 258-264; 2002b; Skružný 1963; 1980; Vignatiová 1992), ale aj v zahraničí (napr. Fodor 1986; Grimm 1969; Méri 1963; Tauber 1980). Poukázali na spoločné znaky, ale aj odlišnosti, ako i stavebné detaily a možnosti využitia v závislosti od situovania $\mathrm{v}$ interiéri domov alebo volne $\mathrm{v}$ rámci sídliska.

Naša pozornost' bude v tomto príspevku zameraná na zahĺbené kupolové pece situované mimo obydlí. Ide o početne zastúpený typ pecí, s ktorým sa možno stretnút vo viacerých regiónoch územia Slovenska (pozri napr. Daňo 1995; Egyházy-Jurovská 1985, 215, 218). Dobre známy je v oblasti Ponitria, kde bol objavený na viacerých sídliskách, predovšetkým z 11. až 13. storočia. Ich počet $\mathrm{v}$ tejto oblasti pritom výrazne stúpol v posledných rokoch. ${ }^{2}$ Ide napríklad o nálezy z Krušoviec, poloha Hrad II (rok 2009; Wiedermann 2015, 37, 43-45, 129, obr. 58, 138), poloha Hrad III (rok 2004; Kopčeková - Bielich 2006; Wiedermann 2015, 67, 69, 70, 71, obr. 84, 85), Nitry, poloha Mlyny (rok 2006; König 2014 a kol., 78), Nitry, poloha Mostná ulica (novšie výskumy v rokoch 2003 - 2006; Březinová - Samuel a kol. 2007, 8, 37, obr. 1), Nitry-Chrenovej, poloha Selenec III (rok 2010; Bielich 2014, 697, obr. 7: 1-3), Nitry-Janíkoviec, poloha Mikov dvor II (rok 2008 - 2010; Ruttkay a kol. 2016, 49, 51, obr. 9),

Kobohateniu tohto stavu prispeli aj dva záchranné výskumy Katedry archeológie FF Univerzity Konštantína Filozofa v Nitre, ktoré neboli dosial' publikované. V roku 2011 bola pri híbení pivnice rodinného domu vo Svätoplukove objavená zahĺbená kupolová pec so schodovito upravenou predpecnou jamou. Druhý nález pochádza z roku 2015, ked’ sa pri výkope základových pásov výrobnej haly v nitrianskej časti Dolné Krškany podarilo odkryt’ sústavu nadväzujúcich objektov s troma pecami. U dvoch $\mathrm{z}$ nich bola pritom jednoznačne zachytená kupola. Na základe objaveného keramického materiálu datujeme pece z oboch lokalít do 12. až na začiatok 13. storočia. Ich spoločným znakom sú pritom stopy po kolovej konštrukcii objavené v blízkosti týchto výrobných objektov. Tie môžu poukazovat na ich možné zastrešenie. Dôležitou otázkou ostáva funkcia pecí, resp. ich spôsob využitia. Zámerom predloženého príspevku je, po podrobnej analýze konštrukcie a rozbore nálezového materiálu, porovnat a vyhodnotit objavené pece v kontexte s analogickými celkami známymi predovšetkým z regiónu Ponitria.

\section{Zahíbená kupolová pec so schodovito upravenou predpecnou jamou vo Svätoplukove}

Archeologický výskum vo Svätoplukove bol vyvolaný novostavbou rodinného domu v zastavanej časti severného okraja obce na parcele č. 12/5 (obr. 1: A). Poloha je situovaná na lavom brehu Mlynského potoka v tesnej blízkosti (cca 150 m juhovýchodne) od známej polykultúrnej archeologickej lokality v polohe Horné Zemky, kde aj v súčasnosti prebieha výstavba rodinných domov a k nim prislúchajúcich komunikácií (Beljak Pažinová - Godiš 2017; Beljak Pažinová Godiš - Bordáč 2017; Beljak Pažinová - Styk - Šimunková 2017; Repka 2017; Štefanovičová Hlavatá - Spišák 2013). Priemerná nadmorská výška na mieste výskumu bola 140,6 m n. m.. Podložie bolo tvorené hutnou žltou sprašou, v ktorej bolo možné zachytit’ vel'mi detailné archeologické objekty. Zemné práce na mieste pivnice (obr. 1: B) rodinného domu porušili až 13 sídliskových objektov (obr. 1: C), z ktorých pochádzali hnutelné nálezy v podobe keramiky, zvieracích kostí a mazanice.

2 Posledný súpis stredovekých pecí z územia Slovenska pochádza z roku 1995 a je súčastou nepublikovanej diplomovej práce (Daňo 1995). 
K výnimočným nálezom patrí zachytenie dobre zachovanej a do sprašového podložia zahĺbenej hlinenej kupolovej pece (obr. 2: C). Vchádzalo sa k nej z východnej strany, kde boli do spraše vyhíbené tri schodíky (obr. 2: B). Tento nález, označený ako objekt 1, sa podarilo takmer kompletne (chýbal len menší kus vrchnej časti kupoly) zdokumentovat'. Nález bol len okrajovo porušený novším zásahom, ktorý tvorila nekompletná kostra zvierata uložená v anatomickej polohe s tvárou smerujúcou na juh. Kostra bola uložená plytko pod dnešným povrchom, pričom zasahovala na rozhranie ornice a sprašového podložia a čiastočne sa dotkla hornej časti kupoly pece (obr. 2: A).

\section{Opis pece:}

Vlastná pec mala v pôdoryse takmer kruhový tvar s priemerom $136 \mathrm{~cm}$ a hlibkou dna $106 \mathrm{~cm}$ (135 cm od súčasného povrchu terénu). Orientovaná bola v smere západ-východ, kupola na západnej strane a predpecná jama s tromi schodíkmi na východnej, pričom celková dĺžka objektu dosahovala $315 \mathrm{~cm}$ (obr. 3). Kupola sa zachovala v zadnej a bočnej časti takmer v celej výške, $\mathrm{v}$ časti od predpecnej jamy bola zničená. Bočná výška zachovaných prepálených stien dosahovala $60-70 \mathrm{~cm}$. V hornej časti hrúbka prepálenej steny dosahovala ešte 10-14 cm. Dno bolo mierne preliačené s pozostatkami jemne vypáleného estrichu (obr. 2: D) a menšími vrstvami uhlíkov (haluzina?). Výraznejšiu vrstvu nad dnom tvorila biela vrstva (vápnito piesčitá) a vrstvy červenohnedej a červenej prepálenej hliny. Väčšia čast’ výplne však pozostávala zo spraše, resp. tmavšej hnedočiernej prachovitej hliny s uhlíkmi a prímesou spraše. Predpecnú jamu predstavovala takmer rovná plocha s dížkou $85 \mathrm{~cm}$ a šírkou $95 \mathrm{~cm}$, od ktorej sa na povrch stúpalo tromi postupne sa zužujúcimi schodíkmi (kým spodný schod dosahoval šírku $90 \mathrm{~cm}$, v prípade vrchného schodíku to bolo už len $50 \mathrm{~cm}$ ). Výška schodíkov sa od spodnej časti postupne zvyšovala od $17 \mathrm{~cm}$, cez $26 \mathrm{~cm}$ až po $34 \mathrm{~cm}$.

S pecou zrejme súviseli aj kolové jamky (objekt 2 a 3) nachádzajúce sa v pravidelnom odstupe od kupoly pece vo vzdialenosti 60-100 cm severozápadným aj juhovýchodným smerom približne rovnakých rozmerov (Ø $50 \mathrm{~cm}$; hlibka 13-17 cm). Ich výplň bola tvorená jednotnou svetlohnedou kyprou vrstvou, v prípade objektu $2 \mathrm{~s}$ nálezmi atypickej stredovekej keramiky (3 ks) a mazanice ( $2 \mathrm{ks}$ ), v objekte 3 žiadne nálezy zaznamenané neboli. V profile mali oba objekty lavórovitý tvar dna, avšak severozápadná stena objektu 3 sa výrazne k okraju zužovala. Koly, ktoré v týchto jamách stáli, mohli tvorit’ súčast prestrešenia výrobného objektu - pece. Pravdepodobná je vzájomná súvislost’ aj s objektom 4, ktorý mal rovnaký priemer $(50 \mathrm{~cm})$ aj híbku $(13 \mathrm{~cm})$ ako opísané kolové jamky v blízkosti pece a zároveň je evidentná pravidelnost vo vzájomnom rozstupe týchto jám (obr. 1: C). Nie je vylúčené, že aj dalšie jamy kruhového pôdorysu (objekty 5-9) zistené na ploche výskumu s výrobným objektom súviseli. Všetky mali rovnakú svetlohnedú výplň a viac-menej okrúhly pôdorys, odlišovali sa však svojím priemerom a hĺbkou (objekt 5: ø $70 \mathrm{~cm}$, hĺbka $7 \mathrm{~cm}$; objekt 6: ø $46 \mathrm{~cm}$, híbka $13 \mathrm{~cm}$; objekt 7: ø 42-46 cm, híbka $28 \mathrm{~cm}$; objekt 8: ø $42 \mathrm{~cm}$, hĺbka $10 \mathrm{~cm}$; objekt 9: ø 38-42 cm, híbka $21 \mathrm{~cm}$ ).

\section{Sústava troch zahíbených pecí v Nitre, čast' Dolné Krškany}

Druhou archeologicky skúmanou lokalitou s nálezom zahĺbených kupolových pecí bola parcela č. 2310/18 na Knappovej ulici, na juhovýchodnom okraji intravilánu nitrianskej mestskej časti Dolné Krškany (obr. 4: B). Na mieste stavby výrobnej haly bolo v nadmorskej výške cca $135 \mathrm{~m}$ n. m. čiastočne zachytených osem sídliskových objektov. Vo východnej časti skúmanej plochy bola zistená vzájomne prepojená sústava štyroch sídliskových objektov (objekt 5-8). Ich súčastou boli tri 
pece zahĺbené priamo do žltého sprašového podložia. V dvoch prípadoch (pec 1 a 3) boli jednoznačne zachytené aj ich hlinené kupoly (obr. 4: C; 5; 6).

\section{Opis pecí:}

Pec 1 bola súčastou objektu 6, pričom jej kúrenisko s pomerne dobre zachovanou kupolou s náznakom komína bolo mierne vysunuté z priestoru objektu (obr. 4: C; 5: A, B; 6: A). Na polkruhovité kúrenisko so šírkou $105 \mathrm{~cm}$ sa v severozápadnej časti napájala plytká predpecná jama. Pec aj s predpecnou jamou dosahovala dĺžku $250 \mathrm{~cm}$. Orientácia pece bola v smere JZ (kupola) - SV. Na okraji predpecnej jamy bola zachytená jedna kolová jama s priemerom $30 \mathrm{~cm}$ (obr. 5: B; 6: A).

Pec 2 sa nachádzala v severovýchodnej časti preskúmanej plochy (obr. 4: C; 5: C). Zistená bola na dne sídliskového objektu 8, pričom sa ju podarilo zachytit iba na západnom okraji objektu. Išlo konkrétne o severný okraj pece, resp. jej predpecnej jamy, ktorá bola zahĺbená do sprašového podložia. Možno však predpokladat, že obdobne ako v prípade pece 1, aj tu išlo o kupolovú pec, pravdepodobne s rovnakou orientáciou v smere JZ - SV (obr. 4: C).

Pec 3 sa nachádzala juhozápadne od pece 1, pričom bola súčastou objektu 7 (obr. 4: C; 5: D; 6: B). Jej orientácia sa zhodovala s orientáciou pece 1 . Hlinená kupola pece bola do značnej miery zničená a jej väčšie torzo pretočené hore nohami bolo objavené v priestore medzi pecou 1 a 3. Zachytená čast' kúreniska mala šírku $111 \mathrm{~cm}$. V západnej časti kupoly bolo možné pozorovat’ náznaky po komíne. Pec prechádzala do hlbšej, smerom ku kúrenisku zošikmenej, predpecnej jamy. Zachovaná dlǐka pece dosahovala hodnotu $193 \mathrm{~cm}$. Na okraji kúreniska bola zachytená plytká jama s priemerom $35 \mathrm{~cm}$. Nie je tu však možné jednoznačne potvrdit', či sa jednalo o kolovú jamu alebo nie (obr. 5: D; 6: B).

Vo výplni všetkých troch pecí a predpecných jám sa nachádzala predovšetkým hrubá vrstva prepálenej zeminy, dalej vrstvičky popola, uhlíkov a kusy mazanice z kupoly (obr. 6). Dno pecí nebolo vymazané a ani prepálené.

\section{Rozbor nálezov}

V prípade oboch skúmaných lokalít bolo zaznamenané polykultúrne osídlenie, kedže nálezy objavené počas výskumu patrili viacerým dejinným obdobiam. V prípade Svätoplukova obsahovali výlučne vrcholnostredoveký materiál len dva objekty (2 a 7). Istotne novoveký bol objekt 11. Ostatné datujeme len velmi rámcovo, pretože neobsahovali žiadny (objekty $3,4,13$ ) alebo len zmiešaný (praveký, stredoveký a novoveký) keramický materiál (objekty 5, 6, 10, 12), prípadne len kúsky mazanice (objekty 8,9). Z ornice pri znižovaní a úprave plochy stavby boli dokonca vyzbierané aj protohistorické črepy, patriace do doby laténskej a rímskej.

Časové zaradenie zahĺbenej kupolovej pece sa opiera predovšetkým o nálezy keramiky získanej zo začistovania schodovito upravenej predpecnej jamy (obr. 7). Väčšinové zastúpenie (66 ks) tu mala stredoveká keramika. V menšej miere (21 ks), s najväčšou pravdepodobnostou v sekundárnej polohe, sa objavili aj praveké črepy. Z priestoru vykurovacej časti pece nálezový materiál, okrem kúskov mazanice, nepochádzal. Uvedené nálezy stredovekej keramiky možno zaradit predovšetkým do obdobia druhej polovice 12. storočia. Takéto datovanie dokladá aj ústie hrncovitej nádoby s nahor vytiahnutým okrajom, ktorý naberá rímsovitý tvar (obr. 7: 2). Tento typ okrajov je známy napr. z Nitry, poloha Mlyny (König a kol. 2014, 53, 84, 87, obr. 26: 28_5). Časovo možno bližšie zaradit aj fragment kalichovito roztvoreného ústia nádoby so zosilneným okrajom, ktorý má vodorovne zrezanú a prežliabnutú vrchnú plochu (obr. 7: 1). Analogické nálezy pochádzajú napríklad z kontextov datovaných mincami z 12. storočia z Krušoviec, poloha Hrad 
(Wiedermann 2015, 43, 56, 57, obr. 69: 6; 70: 1, 4) či zo záveru 12. až prvej polovice 13. storočia z Nitry-Párovských Hájov (Ruttkay 1995, 564, obr. 1: 7). V Nitre, poloha Mlyny sú obdobné nálezy zaradené do mladšej fázy osídlenia lokality, t. j. na koniec 12. a do prvej polovice 13. storočia (König a kol. 2014, 54, 87-90, obr. 27: 28_4, C3_79).

Väčšina fragmentov stredovekej keramiky z výplne pece v Svätoplukove je nezdobená. Iba v siedmich prípadoch sa vyskytujú obežné ryté línie alebo širšie žliabky (obr. 7: 3). Na troch fragmentoch je doložená výzdoba tvorená viacnásobnými hrebeňovými vlnovkami (obr. 7: 4-6). Početné zastúpenie nezdobenej keramiky (56 ks), ako aj nízky výskyt hrebeňovej vlnovky potvrdzuje správnost̉ datovania nálezového súboru stredovekej keramiky z výplne pece do 12. storočia. Na základe spracovania keramických nálezov z viacerých lokalít je možné konštatovat, že aplikácia hrebeňovej vlnovky sa $\mathrm{z}$ keramickej produkcie postupne vytráca v priebehu 12 . storočia. Túto skutočnost' možno dobre pozorovat' na súbore vrcholnostredovekej keramiky z Nitry, poloha Mlyny. V období druhej polovice (poslednej tretiny ?) 11. až prvej štvrtiny 12. storočia tu predstavovala hrebeňová výzdoba ešte dominantný druh výzdoby. V objektoch zaradených do druhej a tretej štvrtiny 12. storočia ju však postupne nahrádza zdobenie jednohrotým nástrojom (König a kol. 2014, 86). Nakoniec, z obdobia záveru 12. až prvej polovice 13. storočia, je v súbore zastúpený len jeden fragment zdobený hrebeňovou vlnovkou (König a kol. 2014, 89, 90). Postupný pokles výskytu hrebeňovej vlnovky v priebehu 12. storočia, eventuálne až na začiatku 13. storočia vidiet' aj na iných lokalitách (napr. Bielich 2014, 692, 694, 696, obr. 4-6; Repka - Pažinová 2012, 278-280, obr. 4-6). V Nitre-Párovských Hájoch, v období záveru 12. až prvej polovice 13. storočia, dokonca absentuje úplne (Ruttkay 1995, 564, 566, 567, obr. 1-3). ${ }^{3}$

Na nálezisku v Dolných Krškanoch pochádza nálezový materiál, vo forme fragmentov keramiky, vhodný na datovanie z objektov 5, 6 a 7, t. j. objekty s pecami 1 a 2. Možno ich zaradit do obdobia stredoveku. Zaujímavé je, že z výplne samotných pecí, kúreniska a ani predpecnej jamy žiadne nálezy nepochádzajú. Výnimku predstavujú iba kusy mazanice z kupoly pecí. Okrem toho bolo možné z preskúmanej plochy časovo zaradit ešte objekt 3 (severozápadná čast' náleziska), ktorý spadá do staršej doby železnej (vekerzugská kultúra)

Z chronologického hladiska je dôležitý nález zlomku tela grafitového hrnca/zásobnice z výplne objektu 7 (jeho súčastou pec 3), ktorý sa vyznačuje širšou a mierne vystupujúcou plastickou lištou na pleciach (obr. 8: 5). Lišta je zdobená proti sebe stojacími šikmými vrypmi usporiadanými do vetvičkového ornamentu. Zásobnice s lištou uvedeného tvaru doplnenou vetvičkovým ornamentom sú charakteristické pre exempláre moravského pôvodu. Na základe typológie Vladimíra Goša a Jiřího Karla (1979, 165, obr. 1: II; 167, 168) možno hovorit’ o type II, ktorý sa na Morave objavuje predovšetkým v druhej polovici 11. storočia s prežívaním aj do nasledujúceho 12. storočia. Uvedené datovanie potvrdzujú aj nálezy z územia Slovenska (Fusek - Spišiak 2005, 318, obr. 18: 3, 12, 13, 15-17), ktoré sú rovnako datované do 11. - 12. storočia (napr. Fusek - Spišiak 2005, 318, 319, obr. 18: 3, 12, 13, 15-17; König a kol. 2014, 85-87, 139, 143; tab. XXIX: 56_8, 56_89, 56_5, tab. XXXIII: 56_7; Šalkovský - Vlkolinská 1987, obr. 12: 7). Ďalšie nálezy, ktoré by potvrdzovali uvedené časové zaradenie, však z objektu 7 k dispozícii nemáme. Okrem opísaného črepu boli vo výplni zistené len tri nezdobené fragmenty z tela nádoby, zvieracie kosti a uhlíky.

Do mladšieho obdobia, konkrétne do záveru 12. až na začiatok 13. storočia možno zaradit keramické nálezy z objektu 6 (jeho súčastou pec 1). Charakteristický pre toto obdobie je okrajový fragment, na ktorom vidiet prechod od nahor vytiahnutého tvaru k rímsovitej profilácii (obr. 8: 1, 2; porovnaj Loskotová - Procházka 1997, 205, 209). Do tohto obdobia zapadajú aj fragmenty nádob

Je však potrebné podotknút, že tu bol dokumentovaný len výber nálezov. 
$\mathrm{s}$ výzdobou v tvare jednohrotých nepravidelných vlnoviek a obvodových žliabkov, ktoré v niektorých prípadoch prechádzajú už do spomínaných nepravidelných vlnoviek (obr. 8: 3, 4).

Rámcovo do záveru 12. a 13. storočia možno datovat aj ojedinelé keramické nálezy z objektu 5. Možno ich však charakterizovat iba výzdobou vo forme žliabkov či technológie výroby obtáčaním s prímesou strednozrnného ostriva v keramickej hmote a nerovnomerným výpalom (obr. 8: 6).

\section{Funkcia pecí}

Dôležitou otázkou je funkcia analyzovaných pecí. Pec zo Svätoplukova sa vyznačuje výrazným zahĺbením a schodovitou úpravou predpecnej jamy (obr. 3). Z hladiska tvaru ju možno teda zaradit do typu I (podla Ruttkay 2002a, 258-260, Abb. 15), resp. typu IV (podla Ruttkay 2002b, 275, fig. 4). Pece tejto konštrukcie sú z územia Ponitria (obr. 12) známe napríklad z Bajča (Ruttkay 2002a, 260, Abb. 15: 1), Branča-Vel'kej Vsi, poloha Arkuš I a Arkuš II (Cheben - Ruttkay - Ruttkayová 1993, 61), Nitry-Dolných Krškán, poloha Tonex (Ruttkay 2004, 154) či Nitry, poloha Selenec III (Bielich 2014, 697, obr. 7: 1-3). V Nitre-Párovských Hájoch bola zachytená sústava až piatich pecí s dvoma schodovitými predpecnými jamami (obr. 9: 1; Ruttkay 1993, 7, obr. 1). V Nitre-Dolných Krškanoch, poloha Knappova ulica (pec 3; obr. 6: B), Komjaticiach (obr. 9: 4; Šalkovský - Vlkolinská 1987, 137, obr. 4: 1), ako aj Krušovciach, poloha Hrad III (obr. 9: 3; Wiedermann 2015, 71, obr. 85) je namiesto schodovitej úpravy predpecná jama zošikmená. Charakteristickým prvkom väčšiny pecí tohto typu je zúženie priestoru prechodu kúreniska do predpecnej jamy (obr. 9: 1-3), ktoré v niektorých prípadoch dosahovalo šírku len cca $50 \mathrm{~cm}$ (Ruttkay 1993, 7, obr. 1). V prípade pece zo Svätoplukova možno pozorovat aj to, že jeho dno bolo len jemne prepálené a nachádzala sa na ňom vrstva popola a uhlíkov. Nad nimi bola zistená biela vápnito-piesčitá a červenohnedá až červená vrstva prepálenej zeminy. Naznačuje to, že sa tu kúrilo materiálom, ktorý rýchlo zhorel (napr. haluzina), a tak nedosiahol vysokú teplotu. Obdobná situácia je popísaná aj pri vyššie spomínaných schodovito upravených peciach z Nitry-Párovských Hájov (Ruttkay 1993, 4, 5) a Nitry-Dolných Krškán, poloha Tonex (Ruttkay 2004, 154). Ďalšie doklady sú známe aj z územia mimo oblasti Ponitria, ako napríklad zo Šamorína (Barteková et al. 2014, 254) či Bieloviec (pec 5; Fusek 2000, 110, 128, obr. 7). V Bielovciach bola pritom zachytená sústava až 13 pecí zoskupených do dvoch radov (Fusek 2000, 109-111, 128, 129, obr. 7). Nevypálené dno tu bolo pritom doložené v piatich prípadoch (pece 5,10 , 12 a 13 v objekte 25 a pec v objekte 24 ). Na dne týchto pecí sa nachádzala vrstva uhlíkov z tenkých konárov a prútia. Nad ňou vrstva prepáleného piesku a hliny. Na základe nálezovej situácie a paleobotanickej analýzy tu bolo možné konštatovat', že oheň v takýchto peciach horel na sypkej piesočnato-hlinitej vrstve umiestnenej nad vrstvou tenkých prútov (z liesky, brestu či vŕby) uložených na samom dne. Z uvedeného vyplýva, že sa na dno pecí spracovávané produkty asi priamo nekládli, pretože by sa znečistili (Fusek 2000, 128). Rudolf Procházka $(2011,238)$ sa vyjadruje o peciach bez výmazu dna a jeho prepálenia ako o zvláštnej skupine s nejasnou funkciou, pričom ale uvažuje o ich spojení s potravinárstvom.

Na základe konštrukčných daností, absencie výmazu dna a otvoru pre únik dymu a, naopak, vrstvy uhlíkov, popola a prepálenej hliny, slúžili takéto pece pravdepodobne na údenie potravín, ako mäso, ryby či syry. Dym sa z takejto pece dostával iba z predného zúženého otvoru do priestoru predpecnej jamy. Nad ňou boli pod dreveným prístreškom - udiarňou (obr. 10), dokladajúci dve kolové jamy (obr. 3), pravdepodobne umiestnené potraviny určené na údenie. O rovnakej funkcii pecí uvedenej konštrukcie uvažuje na základe nálezov z madarskej lokality Tiszalök-Rázompuszta aj István Méri $(1963,277)$. Treba však podotknút, že takto nie je možné definovat každú pec so schodovitou úpravou predpecnej jamy. Potvrdzuje to nález dvoch pecí z Brna, ktoré nemajú zúžené kúrenisko a naopak majú výmaz, resp. viacero reparačných výmazov dna a doložené je aj 
jeho následné prepálenie (Dejmal - Peška 2010, 113, 114, 116, 119-121, obr. 3-6). Autori výskumu ich preto interpretujú ako chlebové pece. Obdobná pec (v objekte 103) bola nájdená aj vo vrcholnostredovekej osade v Mohelnici (Goš 1973, obr. 2), kde sa však predpokladá, že spolu s dalšími 11 pecami slúžila na výpal keramiky.

Zahĺbené kupolové pece s komínom (otvorom pre odvod dymu) z Nitry-Dolných Krškán majú na základe tvaru (obr. 4: C; 6) najbližšie k chlebovým peciam, ktoré boli bežne budované mimo obydlí. Konštrukčne ich možno zaradit do typu II (podla Ruttkay 2002a, 258, 259, 261-263, Abb. 13; 2002b, 275, fig. 4). K blízkym tvarovým analógiám možno zaradit, napr. pec z Bajča (Ruttkay 2002a, 261, 16: 1), Komjatíc, poloha Štrkovec (Šalkovský - Vlkolinská 1987, 140, 166, obr. 7: 5) či Nitry-Janíkoviec (Ruttkay a kol. 2016, 49, 51, obr. 9). Zásadný rozdiel od pecí slúžiacich na pečenie chleba však v prípade dokladov z Nitry-Dolných Krškán vidiet’ v absencii výmazu a výpalu dna. Na základe toho možno, rovnako v prípade pece zo Svätoplukova, konštatovat', že sa $\mathrm{v}$ týchto peciach nedosahovala vysoká teplota. Podporuje to aj prítomnost' kolových jám umiestnených priamo v priestore predpecných jám (obr. 6). Kedže súčastou pecí z Nitry-Dolných Krškán sú aj otvory pre odvod dymu a nie je tu doložené výrazne zúženie priestoru prechodu kúreniska do predpecnej jamy, je nepravdepodobné, že slúžili rovnakému účelu ako pec v Svätoplukove. Do úvahy preto v tomto prípade prichádza skôr činnost', pri ktorej rovnako nebola potrebná vysoká teplota, a to sušenie potravín (obilia, ovocia, mäsa). O nej uvažuje v súvislosti s touto konštrukciou pecí napríklad aj Matej Ruttkay (2002a, 262, 263).

Na viacerých lokalitách, ako napríklad Bratislava, poloha Uršulínska ulica (Lesák 2000, 137, 138, 140, obr. 3), Hurbanovo (Čaplovič 1965, 245), Chlaba (Hanuliak - Zábojník 1981, 507-509), či Velký Grob (Egyházy-Jurovská 1985, 218) bolo zistených viac pecí, umiestnených blízko vedla seba. V niektorých prípadoch vytvárali sústavu na seba priamo napojených pecí, alebo objektov s pecami, ako je tomu aj v prípade nálezu z Nitry-Dolných Krškán. Obdobná sústava zahĺbených kupolových pecí bola zistená aj na d’alších včasno- a vrcholnostredovekých sídliskách. Ich značná čast' je doložená na území Ponitria, a predovšetkým v priestore dnešnej Nitry (obr. 12). Okrem nami skúmaného náleziska na Knappovej ulici v Dolných Krškanoch sa sústavy pecí spomínajú rovnako v Dolných Krškanoch aj o čosi severnejšie na ploche pod dnešnou firmou Tonex (Ruttkay 2004, 153, 154; 2005, 59). Ďalšie doklady sú z Párovských Hájov (sústava 5 pecí; obr. 9: 1; Ruttkay 1993), Šindolky (Fusek 2008), Selenca III (sústava 3 pecí; obr. 11: 2; Bielich 2014, 697, obr. 7: 1-3). $\mathrm{Na}$ hornom Ponitrí bola sústava dvoch pecí zistená v Krušovciach, poloha Hrad III (Kopčeková - Bielich 2006, 111; Wiedermann 2015, 69, 70, obr. 84). Na dolnom zasa na sídlisku v Bajči, kde sú doložené až štyri sústavy pecí (objekty 5, 8, 62A, 80; obr. 11: 1) a v jednom prípade doklad troch pecí umiestnených v jednom objekte (objekt 702; obr. 11: 5; Ruttkay 2002a, 260, obr. 14: $1,2)$. Početná sústava až 13 pecí zoskupených do dvoch radov bola zistená na Poiplí v už spomínaných Bielovciach (obr. 11: 3; Fusek 2000, 109-111, 128, 129, obr. 7). ${ }^{4}$ Okrem územia Slovenska sú viaceré doklady sústav pecí dobre známe aj zo susedného Madarska. Na tomto mieste možno spomenút nálezy z vrcholnostredovekých osád Fenék (Jankovich-Bésán 1991, 186, 187, 199, 200, kép. 3, 4), Hács-Béndekpuszta (Parádi 1967, 25, 26, kép. 5, 6), Rákospalota (Bencze 1999, 15, 47, kép. 17) či Tiszalök-Rázompuszta (Méri 1963, 274, 278, kép. 1: B, kép. 3).

Okrem sústavy pecí s predpokladanou funkciou zameranou na tepelné spracovanie potravín sú známe aj viaceré doklady pecí remeselno-výrobného charakteru. Ide napríklad o hrnčiarske pece. Zo skúmanej oblasti Ponitria pochádza takýto doklad z Krušoviec, poloha Hrad II (obr. 11: 4; Wiedermann 2015, 43-45, 129, obr. 58, 138). Viacero nálezov poznáme aj zo susednej Moravy a Čiech, konkrétne z Mohelníc (Goš 1973, obr. 2), Mstěníc (Nekuda 2000, obr. 168a) či Kostelca nad Orlicí

4 Z územia Slovenska pochádzajú aj dảšie nálezy sústav pecí, ktoré však na tomto mieste nie je potrebné uvádzat'. 
(Richter 1967, obr. 161, 162). Z mad’arských lokalít sem možno zaradit Hács-Béndekpuszta (Parádi 1967, 25, 26, kép. 5, 6), kde v sústave šiestich pecí, bol v jednom prípade zachytený aj rošt, indikujúci vypalovanie keramiky. So sústavou pecí sa stretávame aj pri tavení železa. Až 24 železiarskych pecí, ktorých značná čast’ bola na seba navzájom napojená, poznáme z moravských Želechovíc (Pleiner 1955). Batéria štyroch navzájom spojených železiarskych pecí bola zistená aj v nedalekej Seničke (Hlubek - Šlézar 2014, 587, 588, obr. 5, 12). Ďalšie doklady sú známe aj z Brna (Malý - Zapletalová 2007). Na Slovensku možno v tejto súvislosti spomenút batériu pecí z Gemerského Sadu (Füryová 1993, 43, obr. 3).

Zásadnou otázkou ostáva, $\mathrm{z}$ akého dôvodu boli budované uvedené sústavy pecí. Do úvahy prichádzajú dve hlavné interpretácie. Na jednej strane mohol byt tento stav zapríčinený krátkou životnostou ich hlinenej konštrukcie. Takto je interpretovaná napríklad nálezová situácia v Bielovciach, kde pece zistené v superpozíciách pravdepodobne neboli využívané súčasne, ale budované postupne v priebehu krátkeho časového úseku. Uvedené tvrdenie potvrdzujú aj zničené kupoly pecí (Fusek 2000, 128, 129). Postupné budovanie pecí uvádza aj Matej Ruttkay $(1993,6)$ na lokalite Nitra-Párovské Háje. Na sídlisku v Bajči je doložená dokonca sústava troch za sebou napojených pecí iba s jednou predpecnou jamou (obr. 11: 1; Ruttkay 2002a, 260, Abb. 14: 2). Predpokladá sa, že pece boli budované postupne a funkčná bola vždy posledná vybudovaná pec, pričom predchádzajúca bola zničená (Ruttkay 2002a, 259). Obdobná situácia je doložená aj na lokalite Nitra, poloha Selenec III (obr. 11: 2; Bielich 2014, 697, obr. 7: 1-3).

Na druhej strane, v niektorých prípadoch, máme aj doklady súčasného používania pecí, ktoré slúžili pravdepodobne pre celú osadu a mohli sa používat $\mathrm{k}$ rôznym pracovným činnostiam. Dobrým príkladom je objekt 702 s trojlístkovým pôdorysom z Bajča (obr. 11: 5; Ruttkay 2002a, 262, Abb. 17: 1). Vo všetkých troch častiach bola umiestnená pec, pričom každá z nich pravdepodobne slúžila na iný proces pri spracovávaní polnohospodárskych plodín. V peci „A“ sa pravdepodobne sušili plodiny, čoho dokladom sú početné paleobotanické nálezy. V peci „C“, v ktorej blízkosti sa našla hlinená pražnica, sa realizovalo azda praženie obilia. V poslednej peci, označenej písmenom „B“ sa uskutočňovalo bližšie nešpecifikované spracovávanie plodín (Ruttkay 2002a, $263,264)$.

V prípade nálezovej situácie sústavy objektov s pecami z Nitry-Dolných Krškán, aj ked’ by sa to na základe pôdorysu (obr. 4: C) zdalo, nie je vzájomné porušenie objektov a pecí doložené. Práve naopak, v profile sústavy objektov boli dobre viditelné ich neporušené a podla všetkého zámerne prepojené steny. V nálezovom materiáli z výplne objektov sa síce ukazujú časové rozdiely medzi objektom 7 (jeho súčastou pec 3) a objektami 5 a 6 (jeho súčastou pec 1; pozri čast’ „Rozbor nálezov“). Z dôvodu nízkeho počtu datovatelných nálezov to však nie je možné jednoznačne potvrdit'.

\section{Vyhodnotenie}

Samostatne stojace zahĺbené kupolové pece rozličnej funkcie sú známe na Slovensku už vo včasnoslovanskom období (Fusek - Zábojník 2010, 166-167; Ruttkay 2002b, 9), avšak najviac ich pochádza z obdobia 11. až 13. storočia (Daňo 1995; Habovštiak 1985, 100-103; Egyházy-Jurovská 1985, 218; Ruttkay 2002, 258-264). Uvedené platí aj pre územie Ponitria, čo potvrdzujú nielen dosial publikované nálezy (obr. 12), ale aj v príspevku analyzovaná pec so schodovitou úpravou zo Svätoplukova (druhá polovica 12. storočia) a sústava objektov s troma pecami z Nitry-Dolných Krškán (pec 3 - druhá polovica 11. - 12. storočie ?, pec 1 - koniec 12. - začiatok 13. storočia). Výnimku v tomto smere na uvedenom území predstavuje nález z Bajča, ktorý je datovaný už do 8. - 9. storočia (Ruttkay 2002a, 261, 263). Rovnakú situáciu možno pozorovat aj v okolitých 
krajinách, napríklad v Mad’arsku (Méri 1963, 273-280), v Čechách a na Morave (Procházka 2001, 216; 2011, 242; Skružný 1980, 226, 228; Varadzin 2010, 26, 66-71).

Na základe konštrukčných daností (zahlibenie do podložia, schodovitá úprava predpecnej jamy, kolová konštrukcia - prestrešenie) preskúmaných kupolových pecí zo Svätoplukova a Nitry-Dolných Krškán možno predpokladat ich funkciu zameranú na tepelné spracovanie potravín. Z dôvodu absencie výmazu a výpalu dna a naopak prítomnosti uhlíkov, popola a prepálenej hliny išlo pravdepodobne o činnost', pri ktorej nebola potrebná vysoká teplota, akou je sušenie a údenie.

\section{REFERENCES}

Bencze, Zoltán. 1999. Beszámoló a Rákospalota-Újmajor területén 1995-1997 között folytatott régészeti feltárások középkori eredményeiről. In Bencze, Zoltán et al (eds.). Egy árpád-kori veremház feltárása és rekonstrukciója. Budapest, 9-72.

Beljak Pažinová, Noémi - Godiš, Jakub. 2017. Svätoplukovo, okres Nitra „Rodinný dom“, parc. č. 2360/29, kat.úz. Svätoplukovo: výskumná dokumentácia z archeologického výskumu č. V-KARCH 01/2017/Paz. Nitra, 55 s.

Beljak Pažinová, Noémi - Styk, Matej - Šimunková, Katarína. 2017. Svätoplukovo, okres Nitra „Rodinný dom - Miriama“, parc. č. 2360/19, kat.úz. Svätoplukovo : Výskumná dokumentácia z archeologického výskumu č. V-KARCH 07/2017/Paz. Nitra, 69 s.

Beljak Pažinová, Noémi - Godiš, Jakub - Bordáč, Miloš. 2017. Svätoplukovo, okres Nitra „Rodinný dom s garážou“, parc. č. 2360/21, kat.úz. Svätoplukovo : Výskumná dokumentácia z archeologického výskumu č. V-KARCH 11/2017/Paz. Nitra, 67 s.

Bielich, Mário. 2014. Nález vrcholnostredovekých pecí na polohe Selenec v Nitre. In Archaeologia Historica 39, 689-699.

Březinová, Gertrúda - Samuel, Marián a kol. 2007. Tak čo, našli ste niečo? Svedectvo archeológie o minulosti Mostnej ulice v Nitre. Nitra.

Čaplovič, Dušan. 1965. Včasnostredoveké pohrebisko a sídlisko v Hurbanove. In Slovenská Archeológia 13/1, 237-247.

Čaplovič, Dušan. 1987. Archeologický výskum stredovekého dedinského domu na Slovensku. In Archaeologia Historica 12, 145-155.

Daňo, Róbert. 1995. Samostatne stojace pece zo 6. až 13. storočia na Slovensku. Diplomová práca. Univerzita Komenského v Bratislave. Bratislava.

Dejmal, Miroslav - Peška, Marek. 2010. Nález dvou potravinářských pecí z 12. století z ulice Bašty v Brně. In Archeologia Technica 8, 113-122.

Egyházy-Jurovská, Beáta. 1985. Stredoveké pece na pečenie chleba vo Velkom Grobe (okr. Galanta). In Archaeologia Historica 10, 209-220.

Fodor, Ivan. 1986. Восточные параллели печей вне жилищ на древневенгерских поселениях [Eastern parallels of ovens outside dwellings in Hungarian settlements]. In Acta Archaeologica Scientiarum Hungaricae 38, 185-193.

Fusek, Gabriel 2000. Torzo stredovekého sídliska v Bielovciach. In Slovenská Archeológia 48/1, 101-158.

Fusek, Gabriel. 2008. Vrcholnostredoveké sídlisko v Nitre-Šindolke. In Archaeologia Historica 33, 27-40.

Fusek, Gabriel - Spišiak, Ján. 2005. Vrcholnostredoveká grafitová keramika z Nitry-Šindolky. In Slovenská Archeológia 53/2, 265-336. 
Fusek, Gabriel - Zábojník, Jozef. 2010. Frühslawisches Siedlungsobjekt aus Suchohrad. Zur Problematik der langobardisch-slawischen Beziehungen. In Beljak, Ján - Březinová, Gerta - Varsik, Vladimír (eds). Archeológia barbarov 2009. Nitra, 155-180.

Füryová, Klára. 1993. Nové poznatky o stredovekom železiarstve v Gemeri. Archeologia Technika 8, 35-47.

Goš, Vladimír. 1973. Slovanská osada v Mohelnici. In Archeologické rozhledy 25, 371-380, 483-484.

Goš, Vladimír - Karel, Jiří. 1979. Slovanské a středověké zásobnice ze severní Moravy. In Archeologické rozhledy 31, 163-175.

Grimm, Paul. 1969. Zum Ofen in der frühgeschichtlichen Archäologie. In Archäologisches zu niederdeutsch Döns, bairisch Türnitz. In Ausgrabungen u. Funde 16, 279-282.

Hanuliak, Milan - Zábojník, Jozef. 1981. Najnovšie výsledky výskumu v Chlabe, o. Nové Zámky. In Archaelogia Historica 6, 505-512.

Hlubek, Lukáš - Šlézar, Pavel. 2014. Doklady zpracování železa v raném středověku na území Uničovska a Litovelska. In Archaeologia Historica 39, 593-607.

Cheben, Ivan - Ruttkay, Matej - Ruttkayová, Jaroslava. 1993. Záchranné výskumy na trase výstavby ropovodu v okrese Nitra. In Archeologické výskumy a nálezy na Slovensku v roku 1992, $61,62$.

Jankovich-Bésán Dénes. 1991. Ásatások az Árpád-kori Fenék falu területén 1976-1978. Zalai Múzeum 3, 185-210.

Kopčeková, Monika - Bielich, Mário. 2006. Záchranný archeologický výskum v Krušovciach. In Archeologické výskumy a nálezy na Slovensku v roku 2004, 111, 112.

König, Tomáš a kol. 2014. Nitra-Mlyny. Stredoveké osídlenie lokality. Bratislava.

Langer, Jiří. 1987. Př́spěvek k typologii topeništ'. In Archaeologia Historica 12, 233-243.

Lesák, Branislav. 2000. Stredoveké pece na Uršulínskej ulici v Bratislave. Zborník SNM 94, Archeológia 10, 137-148.

Loskotová, Irena - Procházka, Rudolf. 1997. Keramik von Brno (Brünn) des 12.-13. Jahrhunderts. In Pravěk Nová Ǩada 6, 199-228.

Malý, Karel - Zapletalová, Dana. 2007. Železářská kovovýroba v pravobřežní části Starého Brna. In Archeologia Technica 18, 18-31.

Méri, István. 1963. Árpád-kori szabadban levö kemencék. In Archaeologiai Értesitő 90, 273-281.

Nekuda, Vladimír. 2000. Mstěnice. Zaniklá stř̌edověká ves u Hrotovic 3. Raně středověké sídliště. Brno.

Parádi, Nándor. 1967. A hács-béndekpusztai Árpádkori edényégető kemence. In Archaeologiai Értesitö 94, 20-36.

Pleiner, Radomír. 1955. Výroba železa ve Slovanské huti u Želechovic na Uničovsku. In Rozpravy ČSAV 5, 591.

Procházka, Rudolf. 2001. Chlebové pece predlokačního a lokačního Brna. In Archaeologia Historica 26, 207-219.

Procházka, Rudolf. 2011. Archeologické doklady výroby z 12. - 13./14. století v jihovýchodní části Brna ve vztahu k vývoji zástavby. In FORUM URBES MEDII AEVI VI, 212-251.

Repka, Dominik. 2017. Svätoplukovo, okres Nitra „Rodinný dom - novostavba“ parc.č. 2360/22, k.ú. Svätoplukovo: správa z výskumu. Nitra, 77 s.

Repka, Dominik - Pažinová, Noémi. 2012. Vrcholnostredoveké sídliskové objekty z Podhorian-Sokolníkov. In Archaeologia Historica 37/1, 273-287.

Richter, Miroslav. 1967. Hrnčířské pece v Kostelci nad Orlicí. In Archeologické rozhledy 19, 500-510. 
Ruttkay, Matej. 1990. Pece na ranostredovekých sídliskách juhozápadného Slovenska. In Archaeologia Historica 15, 337-348.

Ruttkay, Matej. 1993. Pece neznámeho účelu z Nitry-Parovských Hájov. In Archeologia Technica 8, 4-8.

Ruttkay, Matej. 1995. Príspevok k poznaniu stredovekej keramiky na juhozápadnom Slovensku. In Archaeologia Historica 20, 563-583.

Ruttkay, Matej. 2002a. Mittelalterliche Siedlung und Gräberfeld in Bajč-Medzi kanálmi (Vorbericht). In Slovenská Archeológia 50/2, 245-322.

Ruttkay, Matej. 2002b. Ovens in the early Medieval settlements of. South - Western Slovakia. In Civilisations 49/1-2, 271-283.

Ruttkay, Matej. 2004. Záchranný výskum v Nitre-Dolných Krškanoch. In Archeologické výskumy a nálezy na Slovensku v roku 2003, 153-154.

Ruttkay, Matej. 2005. Niektoré nové objavy v Nitre a okolí zo včasného a vrcholného stredoveku. In Ruttkay, Matej (ed.). Dávne dejiny Nitry a okolia. Nitra, 55-75.

Ruttkay, Matej a kol. 2016. Sídlisko z 10. - 12. storočia v Nitre-Janíkovciach. In Archaeologia Historica 41/2, 41-57.

Skružný, Ludvík. 1963. Příspěvek k třídění a chronologii slovanských otopných zařízení na území ČSSR. In Památky archeologické 54, 234-265.

Skružný, Ludvík. 1980. Několik poznámek k otázce vývoje a funkce pece ve slovanských, středověkých a novověkých objektech i mimo ně. In Archaeologia Historica 5, 22-242.

Šalkovský, Peter - Vlkolinská, Ivona. 1987. Včasnostredoveké a vrcholnostredoveké sídlisko v Komjaticiach. In Študijné Zvesti Archeologického ústavu SAV 23, 127-172.

Štefanovičová, Tatiana - Hlavatá, Jana - Spišák, Pavol. 2013. Záchranný výskum v obci Svätoplukovo. In Archeologické výskumy a nálezy na Slovensku v roku 2009, 252-254.

Tauber, Jürg. 1980. Herd und Ofen im Mittelalter: Untersuchungen zur Kulturgeschichte am archäologischen Material vornehmlich der Nordwestschweiz (9.-14. Jahrhundert). Olten.

Vályi, Katalin. 1992. Külső kemencék Szer Árpád-kori településén. In A Móra Ferenc Múzeum évkönyve 1989-1990/1, 135-157.

Varadzin, Ladislav. 2010. Hrnčířská výroba ve východní části stř̌ední Evropy 6. - 13. století v archeologických pramenech. In Archeologické rozhledy 62, 17-71.

Vignatiová, Jana. 1992. K otázce púvodu a funkce hliněných pecí v zemnicích 9. stol. na Moravě a na Slovensku. In Sborník prací Filozofické fakulty Brněnské univerzity E 37, 89-102.

Wiedermann, Egon. 2015. Topolčany Hrad: Protourbánne sídlo. Nitra.

SUMMARY: MEDIEVAL RECESSED CUPOLA OVENS FROM THE NITRA REGION. Finds of recessed cupola ovens are common in the Nitra region from the Early and beginning of High Middle Ages. New features were excavated in 2011 and 2015 by the Department of Archaeology at the Constantine the Philosopher University in Nitra. A system of three connected recessed cupola ovens was found in Nitra, Dolné Krškany during a rescue excavation at Knappova Street (parcel No. 2310/18). In at least two cases, these included cupola ovens recessed directly into the ground. Postholes, excavated in the stokeholes, demonstrate the presence of an above-ground post construction. Based on the unique find material, they can be dated primarily to the period between the 12th to the early 13th century. Another find of a recessed cupola oven and three well-preserved entry steps carved into the sub-soil was discovered in Svätoplukovo (parcel No. 12/5). In the vicinity of the ovens, several postholes were observed that could have been part of a roofing. This unit was discovered during a rescue excavation in the cellar of a new single-family house. Even in this case, we cannot rule out the existence of a system of clay cupola ovens. The material suggests dating to the second half 
of the 12th century. In addition to their placement in the ground and the presence of a clay cupola, ovens from both sites also display traces of possible roofing.

The system of ovens deeply dug into the subsurface was discovered at various Early and High medieval settlements dating from the 11th century to the beginning of the 13th century. In Slovakia, their concentration is significant predominantly in the Nitra region, e.g. in Bajč, Nitra, Selenec III; Nitra-Párovské Háje and Nitra-Šindolka. In the case of Párovské Háje, a special type of oven with step-like entrances (similar to the one in Svätoplukovo) was present. The function of these ovens has not been specified yet. It is being considered that they were used for farming purposes, such as drying grains, fruit and meat, or for smoking. It is also possible that the oven networks were not used together but were constructed successively in a short period of time.

Mgr. Dominik Repka, PhD.

Constantine the Philosopher University in Nitra

Faculty of Arts

Department of Archaeology

Hodžova 1

94974

Nitra

Slovakia

drepka@ukf.sk

doc. PhDr. Noémi Beljak Pažinová, PhD.

Constantine the Philosopher University in Nitra

Faculty of Arts

Department of Archaeology

Hodžova 1

94974

Nitra

Slovakia

nbpazinova@ukf.sk 


\section{Prílohy / Appendix}
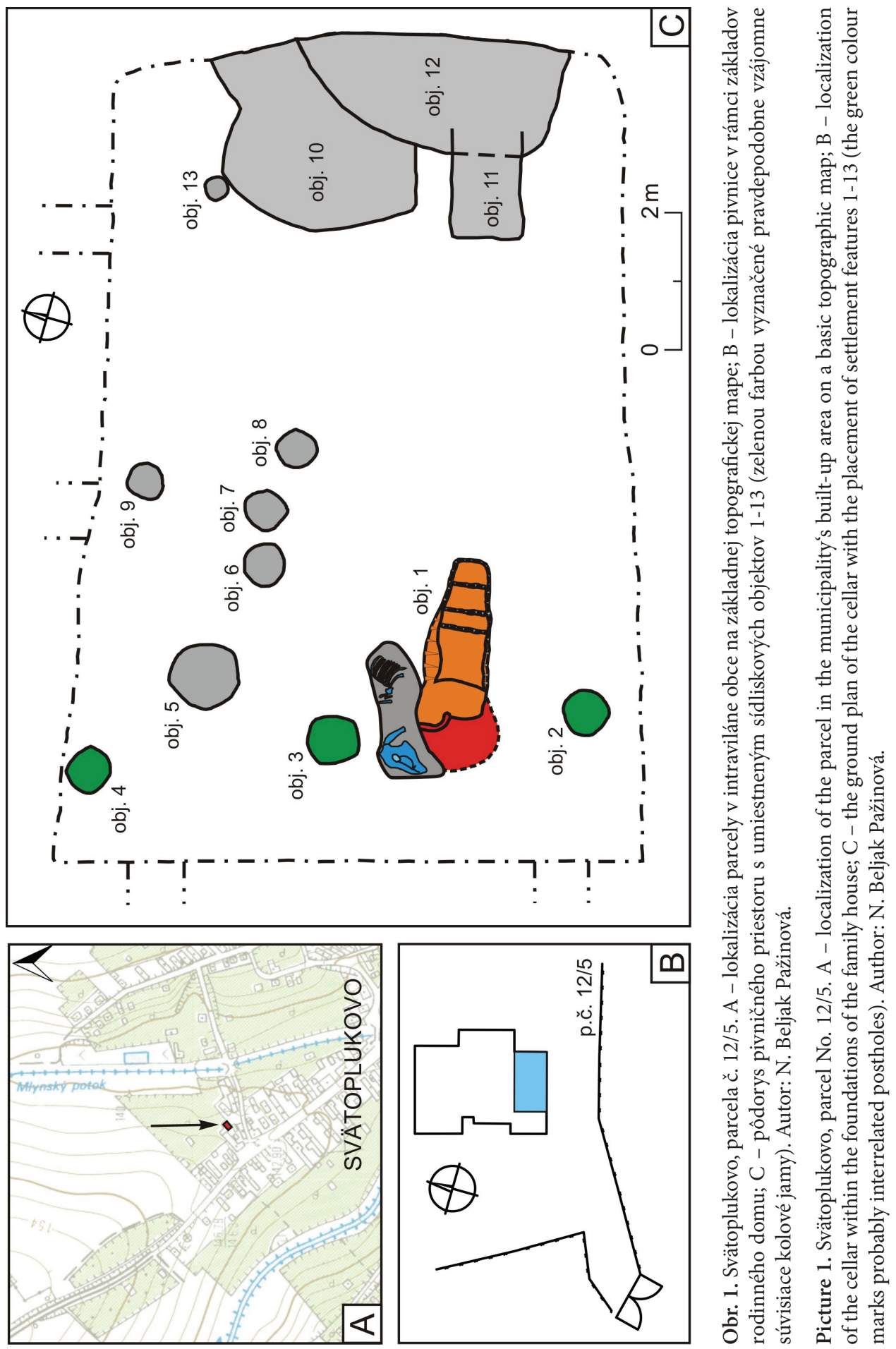

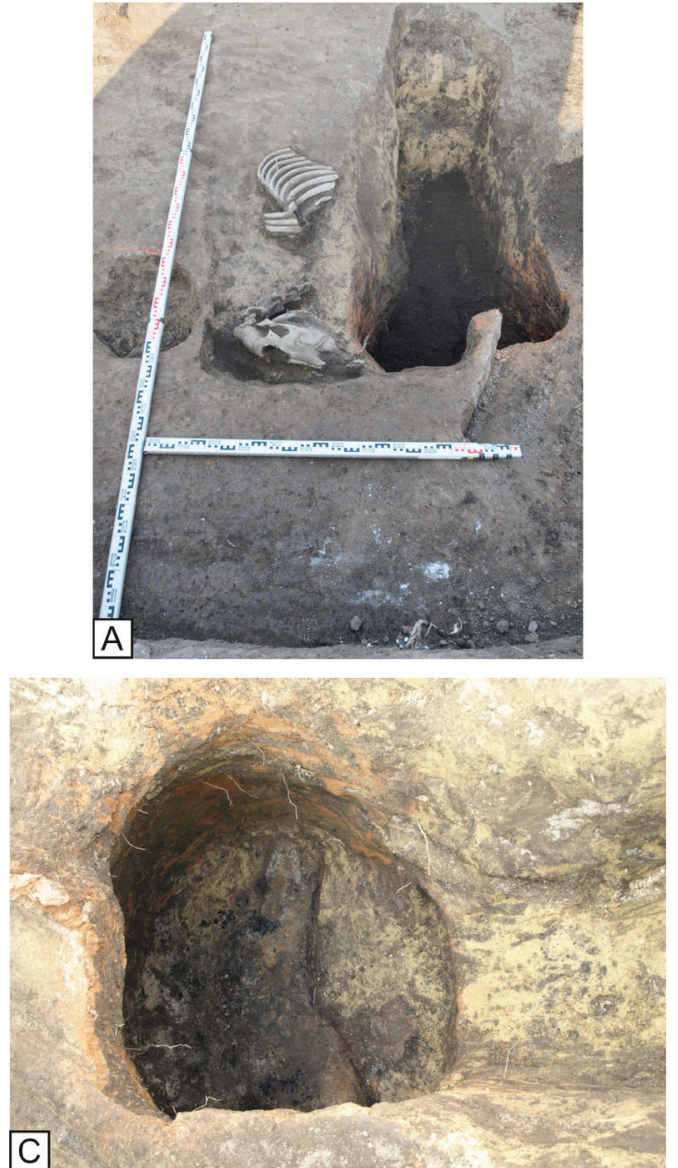
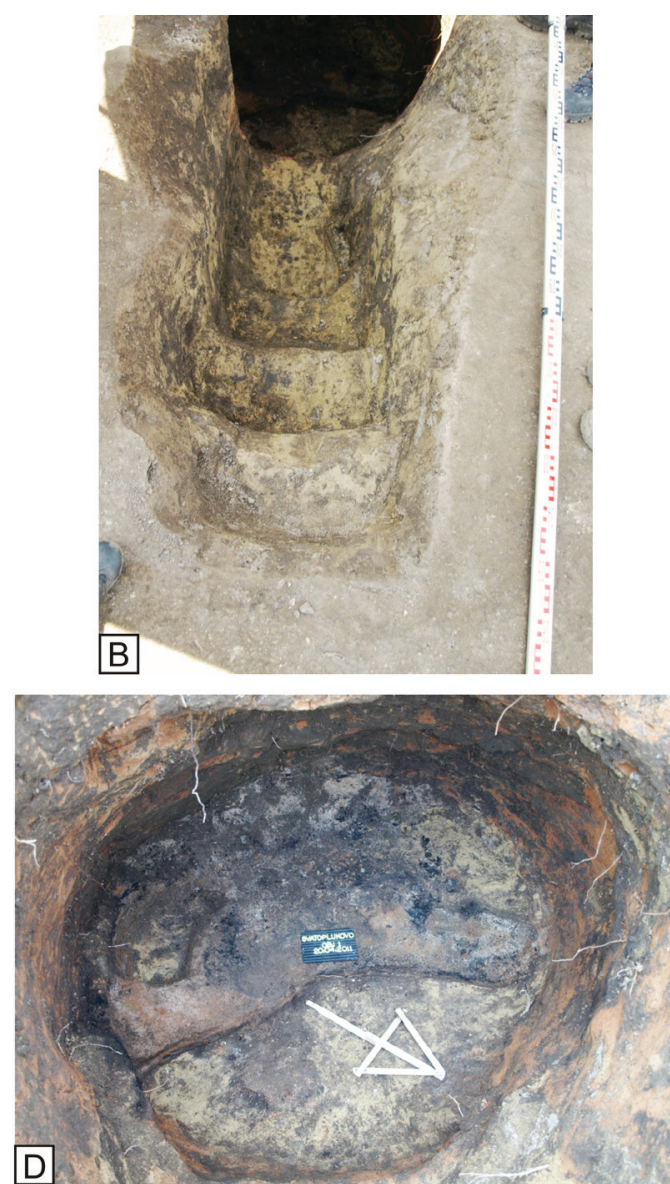

Obr. 2. Svätoplukovo, parcela č. 12/5. Objekt 1 - kupolová pec so schodovitou úpravou predpecnej jamy. A - pohlad na novoveký zásah nad kupolou pece; B - schodíky vedúce $\mathrm{k}$ peci vyhĺbené do žltej spraše; $\mathrm{C}$ - zahĺbená kupolová pec; $\mathrm{D}$ - pomerne rovné dno pece s jemne vypáleným estrichom, uhlíkmi, popolom. Foto: N. Beljak Pažinová, O. Žaár.

Picture 2. Svätoplukovo, parcel No. 12/5. Feature 1 - cupola oven with a step-like entry pit. A - view of the modern interference over the cupola oven; B - stairs leading to an oven dug out into a yellow loess; $\mathrm{C}$ - recessed cupola oven; D - a fairly straight bottom of the oven with a finely fired clay lining, carbon, ash. Photo: N. Beljak Pažinová, O. Žaár. 


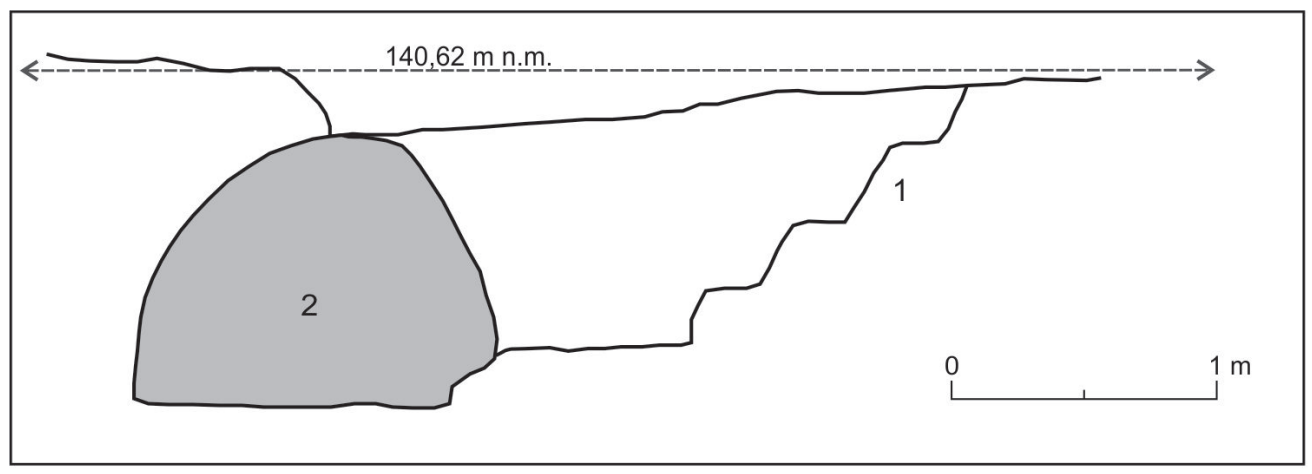

objekt 3

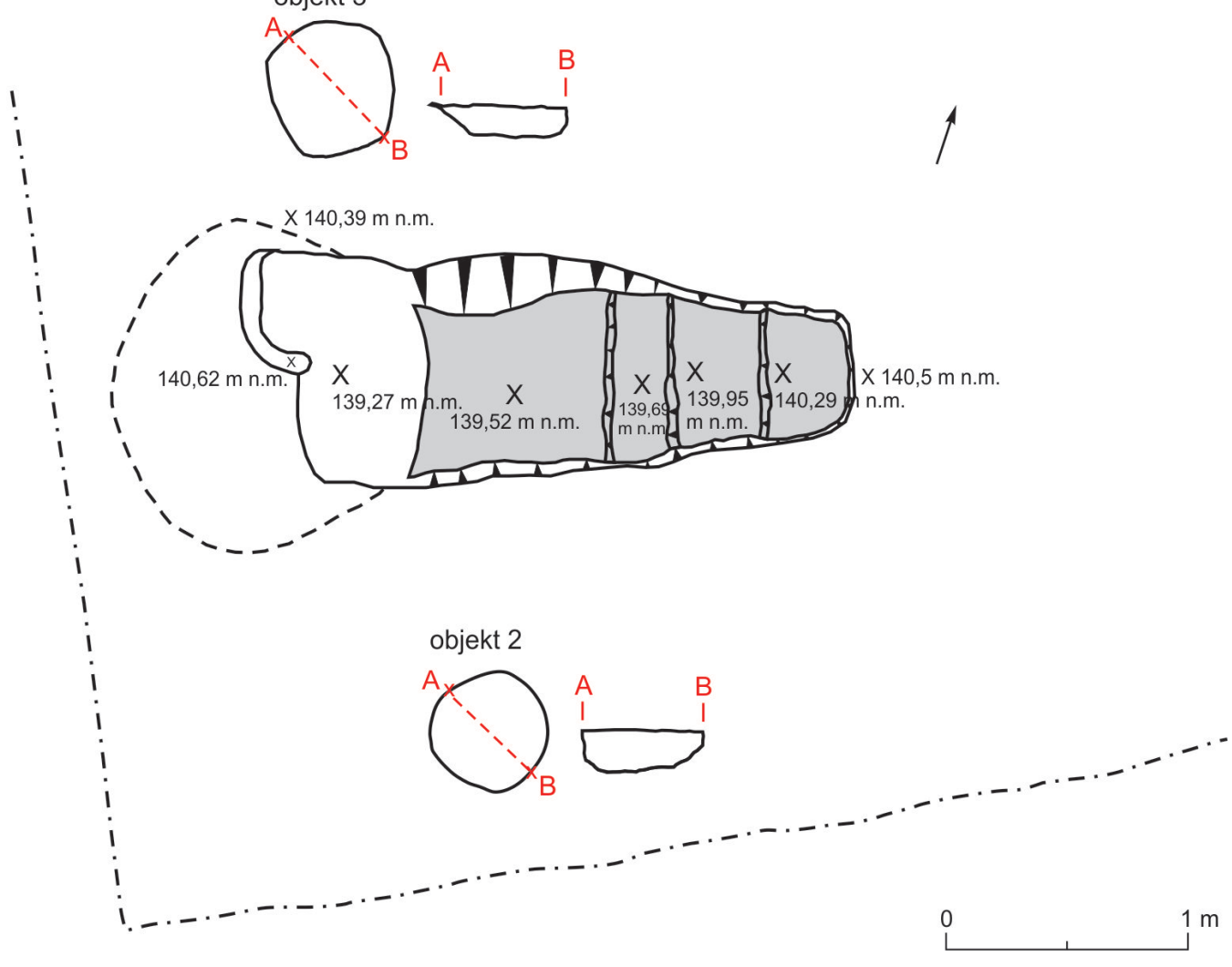

Obr. 3. Svätoplukovo, parcela č. 12/5. Objekt 1 - kupolová pec so schodovitou úpravou predpecnej jamy. Hore - profil objektu 1: 1 - žltá sprašová vrstva (podložie); 2 - prepálený oranžový estrich - kupola pece; Dole - pôdorys objektu 1 a v jej blízkosti situovaných kolových jamiek (objekty 2 a 3), červenou farbou vyznačené profily kolových jám. Autor: O. Žaár, B. Šebesta, N. Beljak Pažinová.

Picture 3. Svätoplukovo, parcel No. 12/5. Feature 1 - cupola oven with a step-like entry pit. Above - profile of the feature 1: 1 - a layer of yellow loess (subsoil); 2 - fired orange clay lining - cupola of the oven; Below the ground plan of feature 1 and adjacent postholes (features 2 and 3), the red colour marks the profiles of the postholes. Author: O. Žaár, B. Šebesta, N. Beljak Pažinová. 

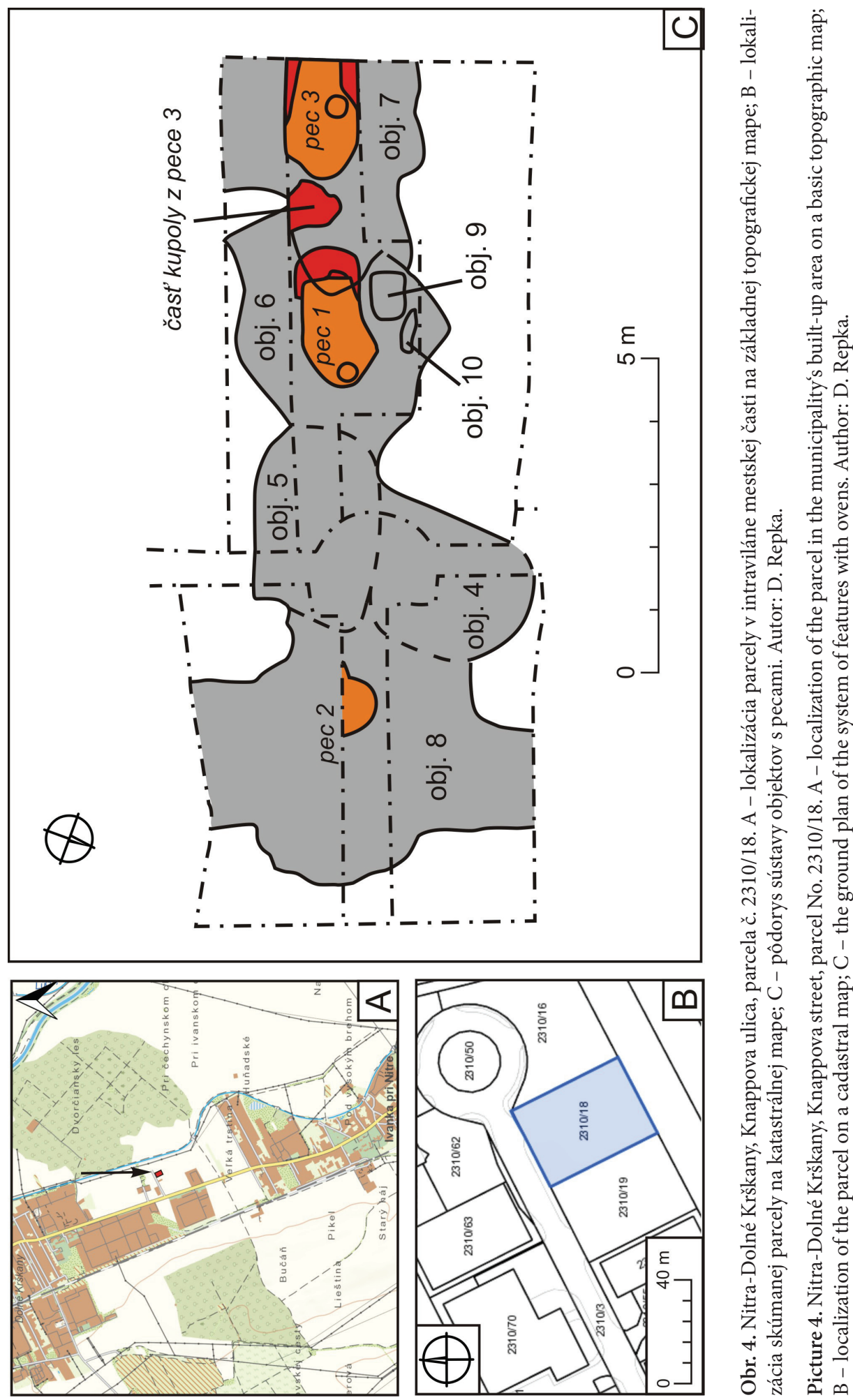

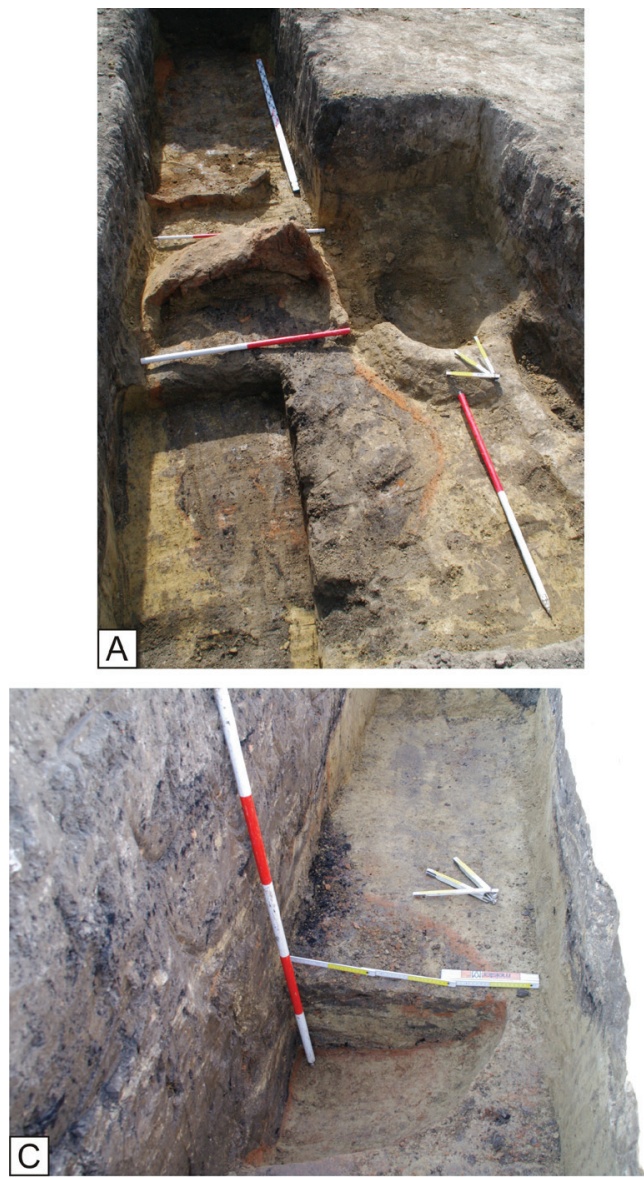
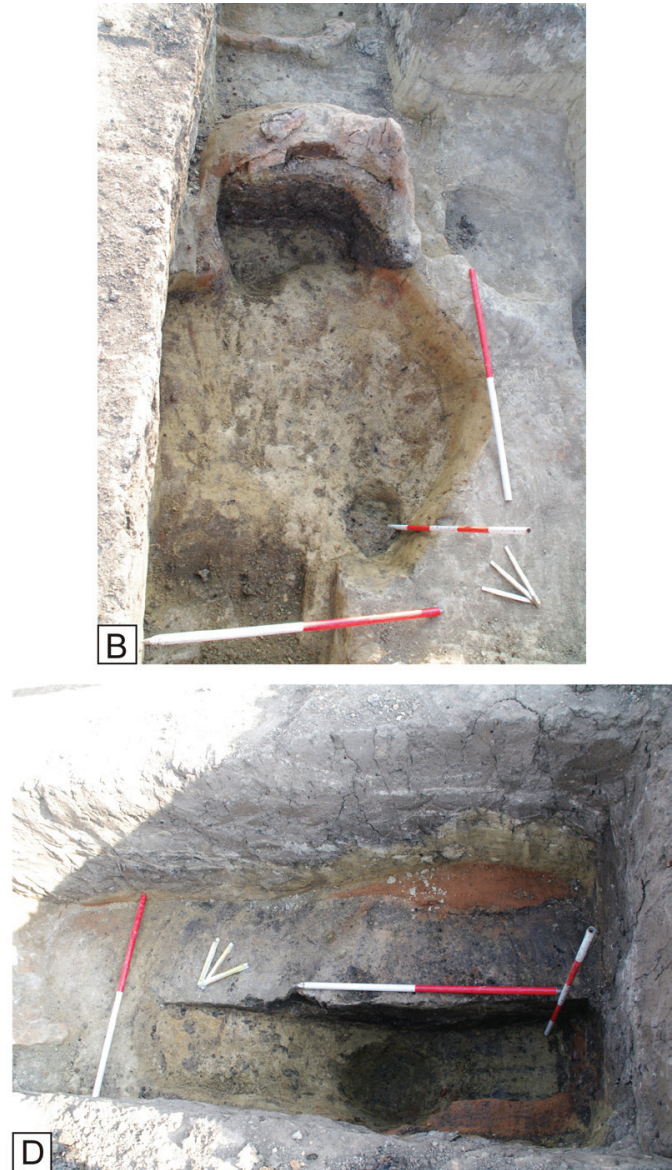

Obr. 5. Nitra-Dolné Krškany, Knappova ulica, parcela č. 2310/18. A, B - pohlad na pec 1 z juhovýchodu; C - rez predpecnej jamy pece 2; D - pohlad na pec 3 zo severozápadu. Foto: D. Repka.

Picture 5. Nitra-Dolné Krškany, Knappova street, parcel No. 2310/18. A, B - view of oven 1 from the southeast; $\mathrm{C}$ - profile of the step-like entrance 2; D - view of oven 3 from the northeast. Photo: D. Repka. 


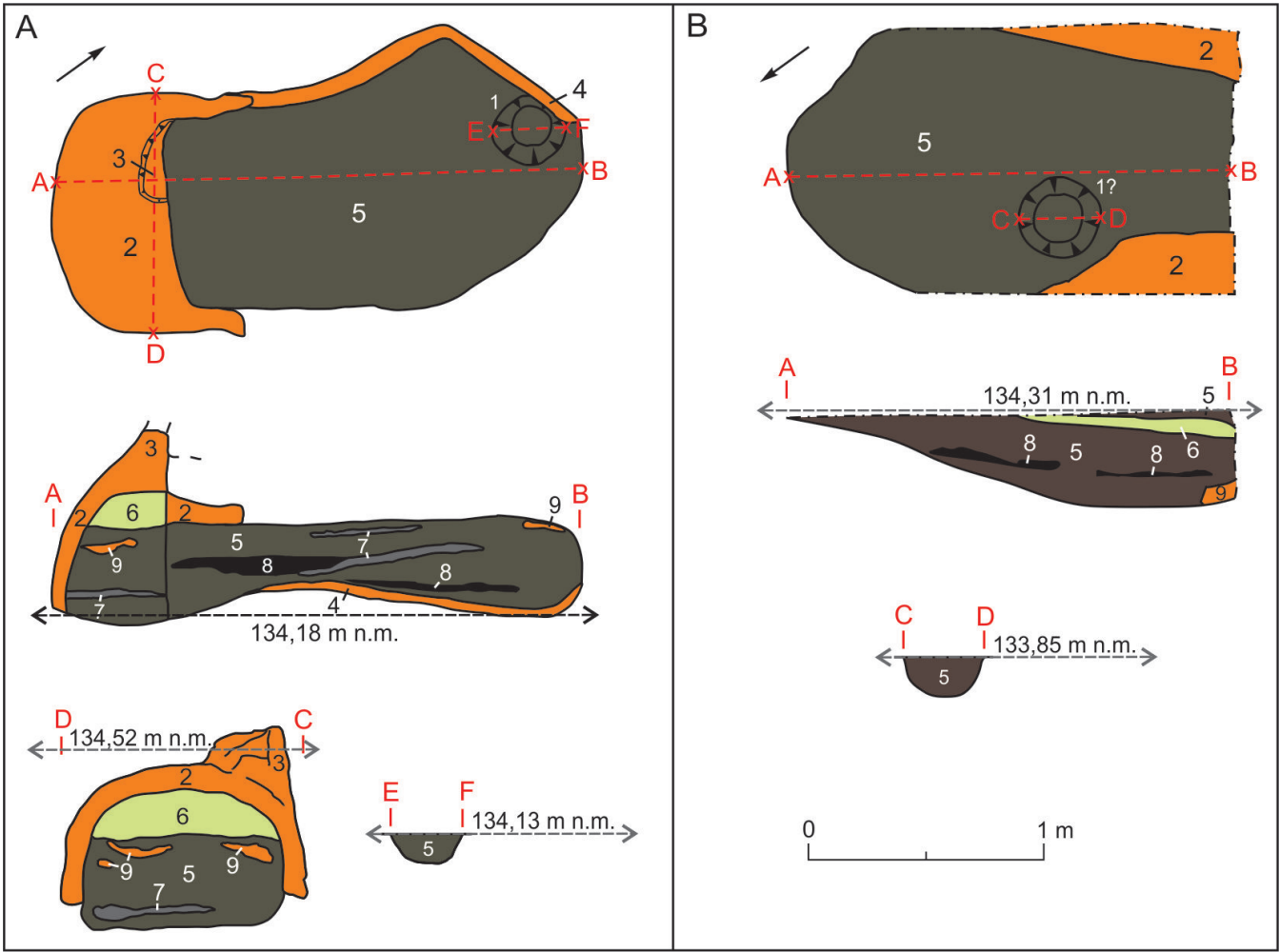

Obr. 6. Nitra-Dolné Krškany, Knappova ulica, parcela č. 2310/18. A - pec 1; B - pec 3; 1 - kolová jama; 2 hlinená kupola; 3 - komín; 4 - estrich; 5 - tmavohnedá prepálená hlina premiešaná so žltým ílom a uhlíkmi; 6 - žltá ílovitá hlina; 7 - sivá popolovitá vrstvička; 8 - čierna prepálená hlina s uhlíkmi; 9 - väčšie kusy mazanice z kupoly alebo estrichu pece. Autor: D. Repka.

Picture 6. Nitra-Dolné Krškany, Knappova street, parcel No. 2310/18. A - oven 1; B - oven 3; 1 - posthole; 2 - clay cupola; 3 - chimney; 4 - fired clay lining in the bottom; 5 - dark brown fired clay mixed with yellow clay and carbon; 6 - yellow clay; 7 - grey ash layer; 8 - black fired clay with carbon; 9 - bigger chunks of mixed clay from the cupola and the fired clay lining of the oven. Author: D. Repka. 

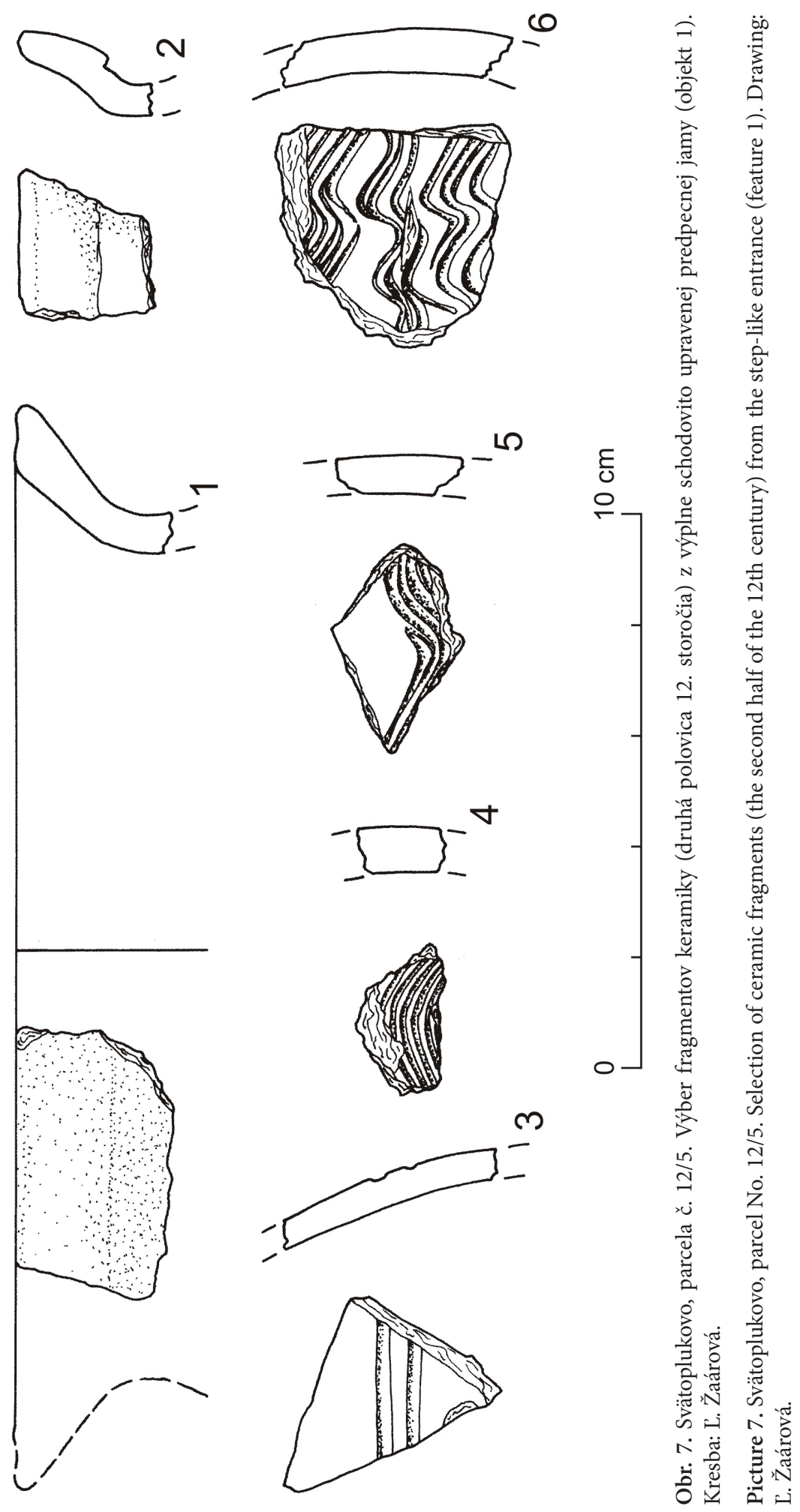

•.• KONŠTANTÍNOVE LISTY 11 / 1 (2018), pp. 16 - 39 

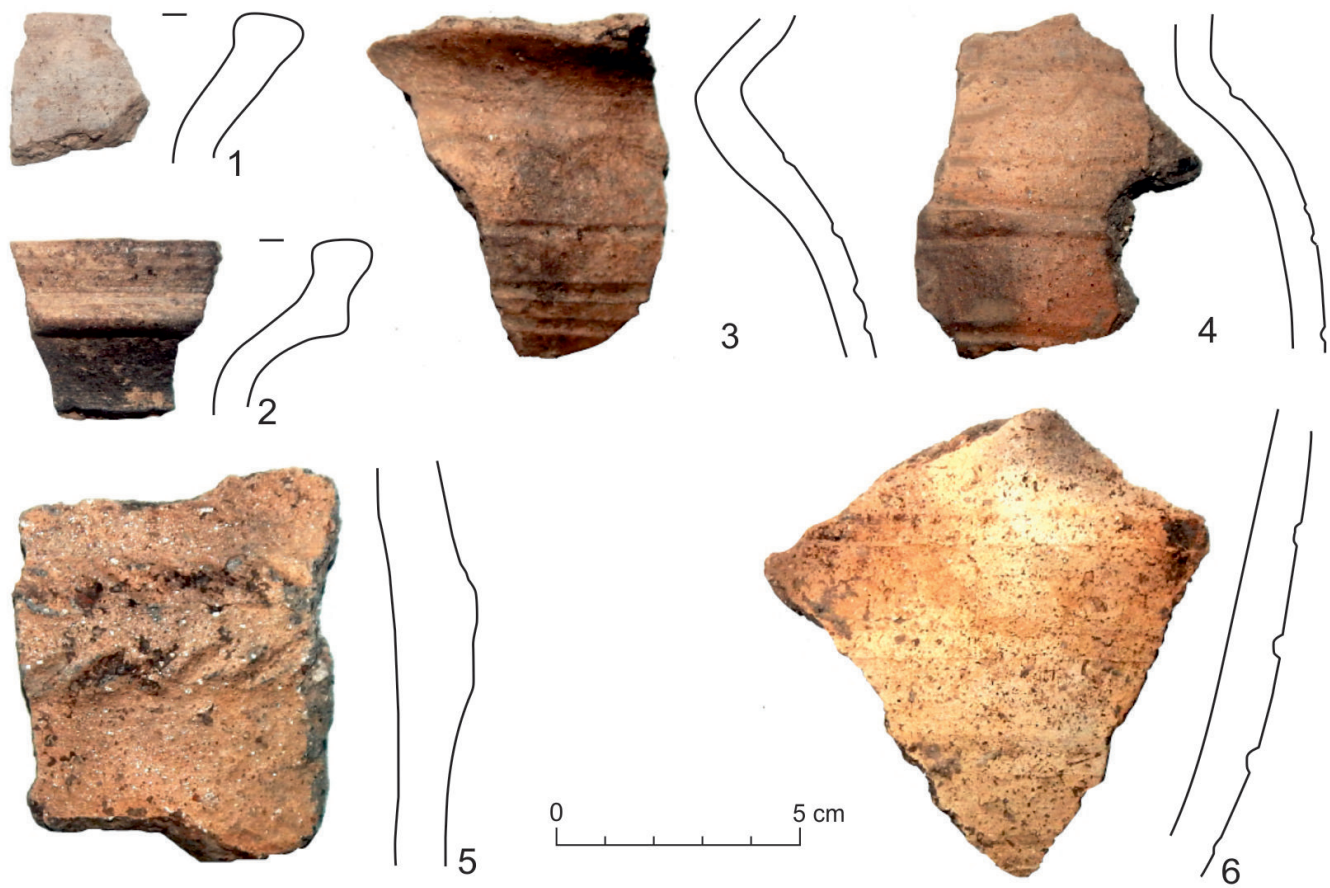

Obr. 8. Nitra-Dolné Krškany, Knappova ulica, parcela č. 2310/18. 1, 3, 4 - fragmenty keramiky z objektu 6 (záver 12. - začiatok 13. storočia); 5 - fragment keramiky z objektu 7 (druhá polovica 11. storočia - 12. storočie); 6 - fragment keramiky z objektu 5 (12. - 13. storočie). Foto, Kresba: D. Repka.

Picture 8. Nitra-Dolné Krškany, Knappova street, parcel No. 2310/18. 1, 3, 4 - ceramic fragments from feature 6 (the end of the 12th - the beginning of the 13th century); 5 - ceramic fragments from feature 7 (the second half of the 11th century - 12th century); 6 - ceramic fragment from feature 5 (12th - 13th century). Photo, Drawing: D. Repka. 

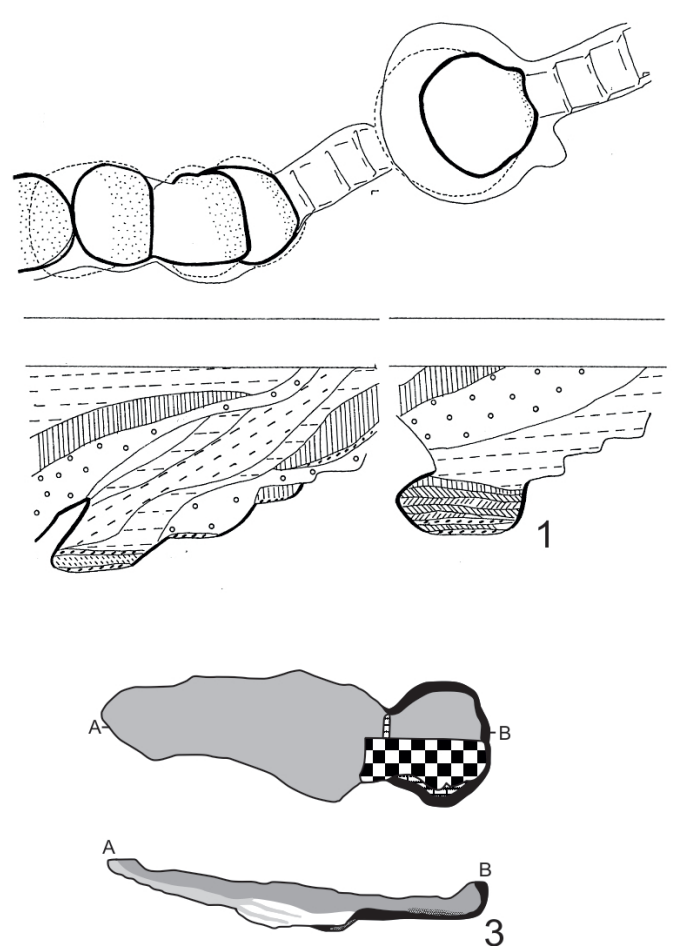
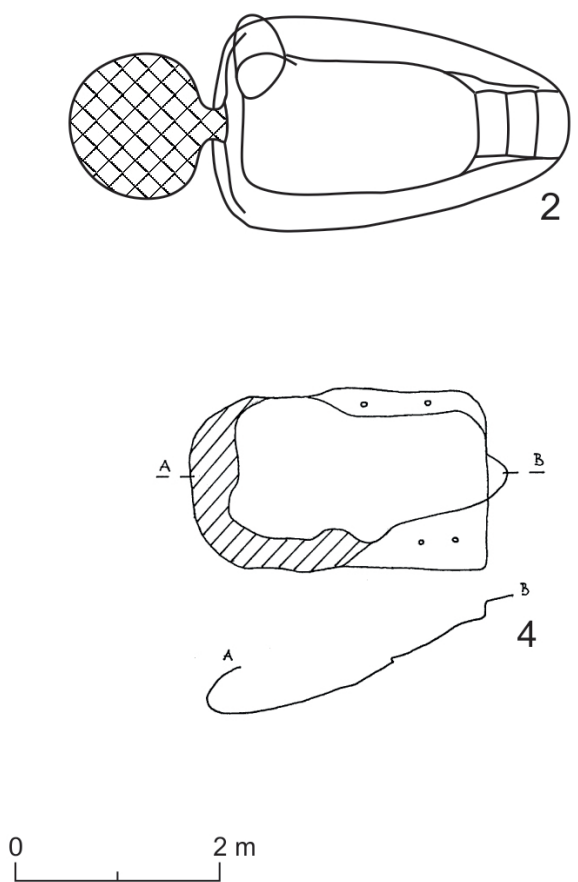

Obr. 9. Zahĺbené kupolové pece so schodovitou úpravou predpecnej jamy. 1 - Nitra-Párovské Háje, poloha stavba štvrtej vetvy plynovodu, objekt 5 (podla Ruttkay 1993); 2 - lokalita Tiszalök-Rázompuszta (podla Fodor 1986); 3 - Krušovce, poloha Hrad III, objekt 4 (podla Wiedermann 2015); 4 - Komjatice, poloha Štrkovisko, objekt 10 (podla Šalkovský - Vlkolinská 1987).

Picture 9. Recessed cupola ovens with a step-like entrance. 1 - Nitra-Párovské Háje, site construction of the fourth branch of the gas pipeline, feature 5 (according to Ruttkay 1993); 2 - site Tiszalök-Rázompuszta (according to Fodor 1986); 3 - Krušovce, site Hrad III, feature 4 (according to Wiedermann 2015); 4 Komjatice, site Štrkovisko, feature 10 (according to Šalkovský - Vlkolinská 1987). 


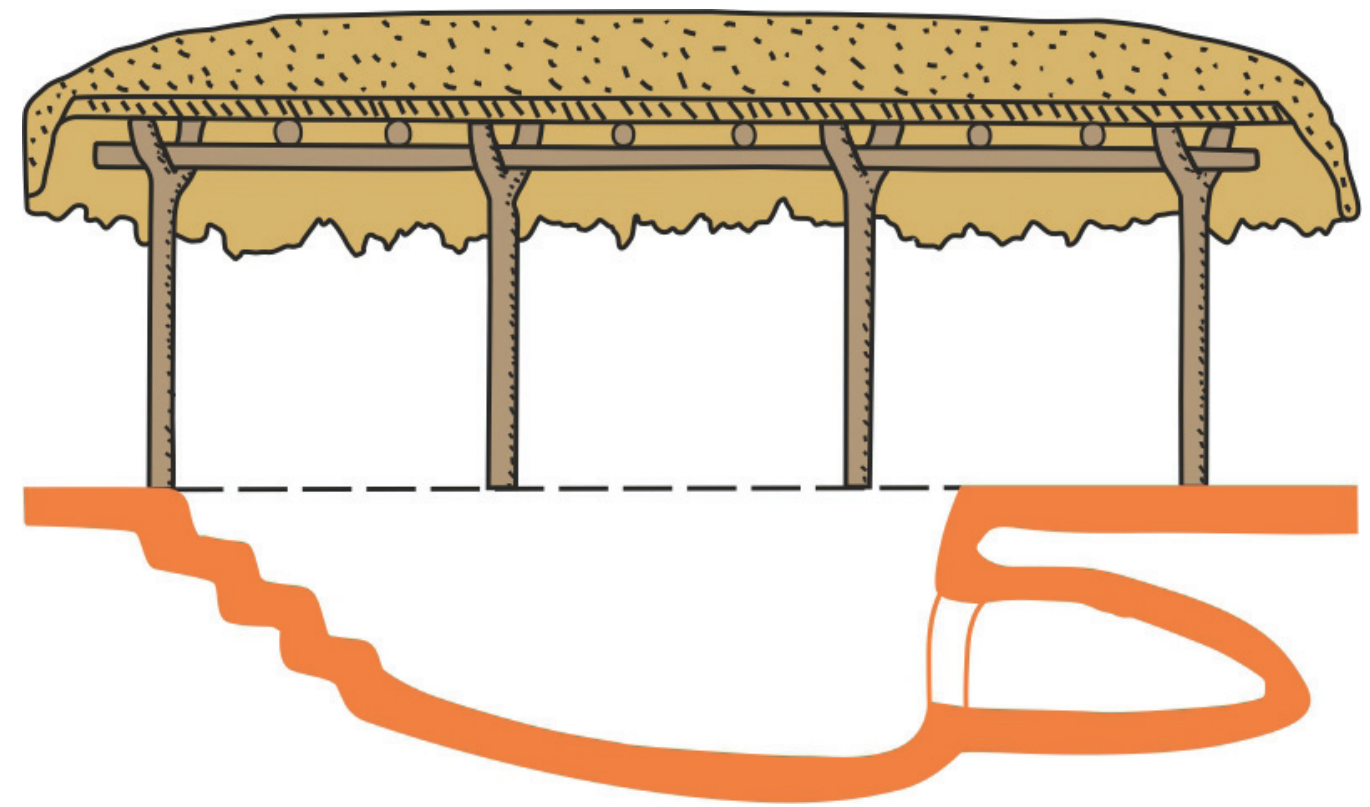

Obr. 10. Rekonštrukcia pece so schodovitou úpravou predpecnej jamy a nadzemnej kolovej konštrukcie (upravené podla Fodor 1986).

Picture 10. Reconstruction of the oven with a step-like entrance and over ground post construction (modified according to Fodor 1986). 

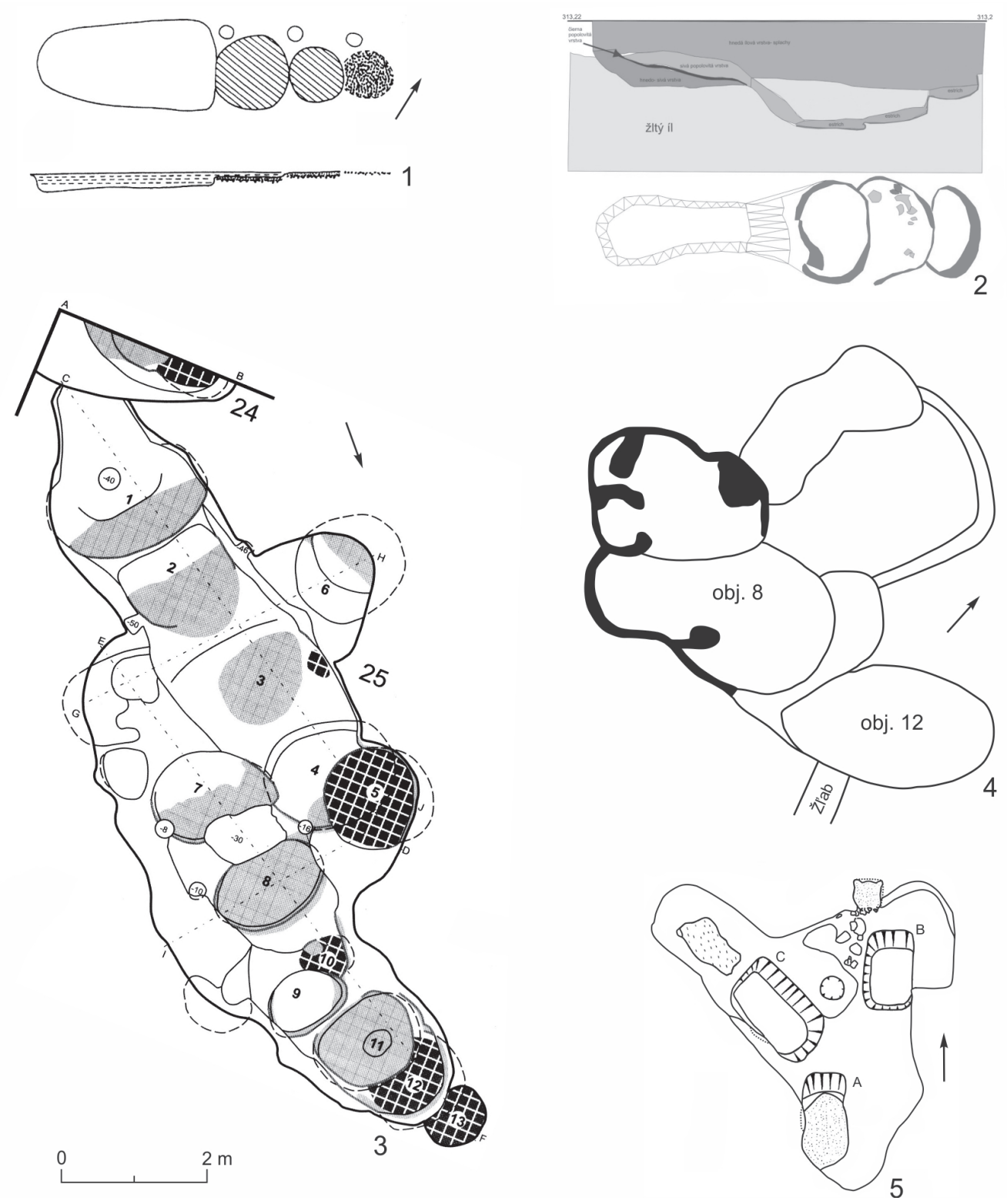

Obr. 11. Sústavy zahíbených kupolových pecí. 1 - Bajč, poloha Medzi kanálmi, objekt 8 (podla Ruttkay 2002a); 2 - Nitra-Chrenová, poloha Selenec III, objekt 4 (podla Bielich 2014); 3 - Bielovce, poloha Telek, objekty 24 a 25 (podla Fusek 2002); 4 - Krušovce, poloha Hrad II, objekty 8 a 12 (podla Wiedermann 2015); 5 - Bajč, poloha Medzi kanálmi, objekt 702 (podla Ruttkay 2002a).

Picture 11. Systems of recessed cupola ovens. 1 - Bajč, site Medzi kanálmi, feature 8 (according to Ruttkay 2002a); 2 - Nitra-Chrenová, site Selenec III, feature 4 (according to Bielich 2014); 3 - Bielovce, site Telek, features 24 and 25 (according to Fusek 2002); 4 - Krušovce, site Hrad II, features 8 and 12 (according to Wiedermann 2015); 5 - Bajč, site Medzi kanálmi, feature 702 (according to Ruttkay 2002a). 


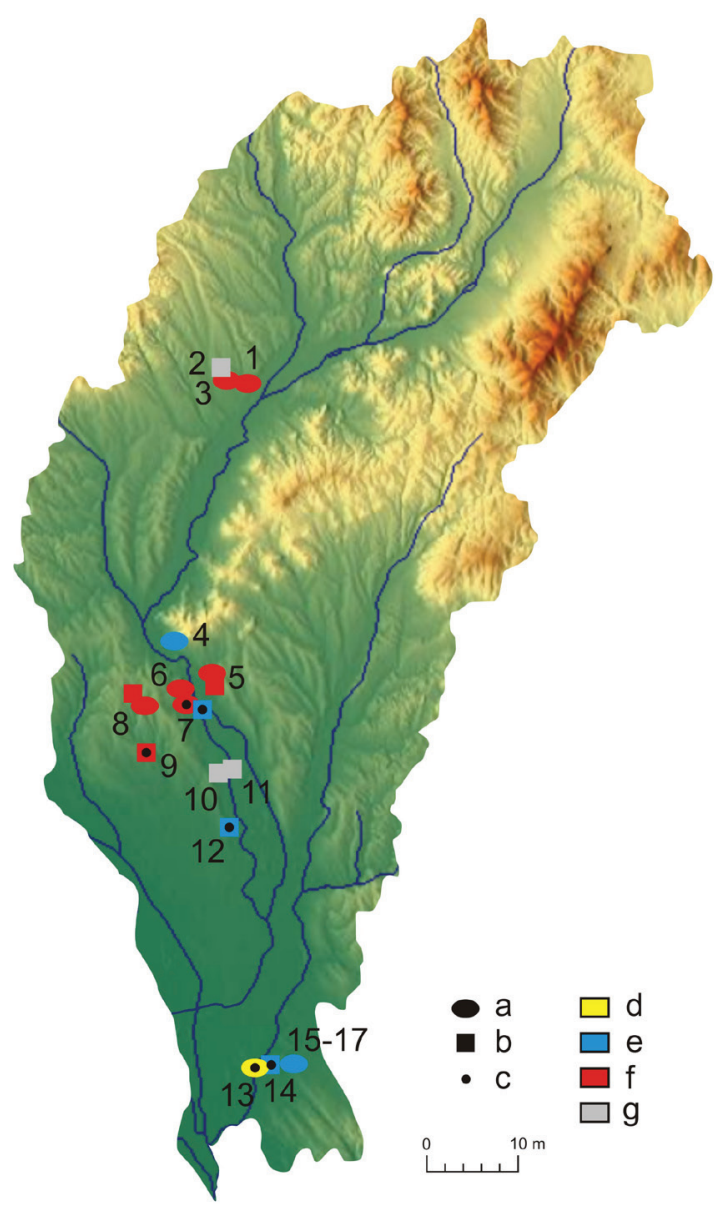

Obr. 12. Územia Ponitrie s nálezmi sústav pecí a pecí so schodovitou úpravou uvádzaných $\mathrm{v}$ texte. ${ }^{1} \mathrm{a}-$ sústava pecí, b - schodovitá úprava pecí; c - pece s kolovými jamami; d - 8. - 9. storočie; e - 11. - 12. storočie; f - 12. - 13. storočie; g - stredovek, bez bližšieho datovania. 1 - Krušovce, poloha Hrad II; 2, 3 Krušovce, poloha Hrad III; 4 - Nitra, poloha Šindolka; 5 - Nitra-Chrenová, poloha Selenec III; 6 - NitraDolné Krškany, poloha Tonex; 7 - Nitra-Dolné Krškany, Knappova ulica; 8 - Nitra-Párovské Háje, poloha stavba štvrtej vetvy plynovodu; 9 - Svätoplukovo, parcela č. 12/5; 10 - Branč-Velká Ves, poloha Arkuš I; 11 - Branč-Vel'ká Ves, poloha Arkuš II; 12 - Komjatice, poloha Štrkovisko; 13-17 - Bajč, poloha Medzi kanálmi. Autor: D. Repka.

Picture 12. The Nitra region with finds of systems of ovens and ovens with step-like entrances mentioned in the text. ${ }^{2} \mathrm{a}$ - the system of ovens, $\mathrm{b}$ - step-like modification of the oven; $\mathrm{c}$ - ovens with the postholes; $\mathrm{d}$ 8th - 9th century; e - 11th - 12th century; f - 12th - 13th century; g - Middle Ages, unspecified dating. 1 Krušovce, site Hrad II; 2, 3 - Krušovce, site Hrad II; 4 - Nitra, site Šindolka; 5 - Nitra-Chrenová, site Selenec III; 6 - Nitra-Dolné Krškany, site Tonex ; 7 - Nitra-Dolné Krškany, Knappova street; 8 - Nitra-Párovské Háje, site construction of the fourth branch of the gas pipeline; 9 --Svätoplukovo, parcel No. 12/5; 10 - Branč-Vel'ká Ves, site Arkuš I; 11 - Branč-Vel'ká Ves, site Arkuš II; 12 - Komjatice, site Štrkovisko; $13-17$ - Bajč, site Medzi kanálmi. Author: D. Repka.

Cielom príspevku nie je vytvorit’ súpis všetkých nálezov uvedeného typu pecí z územia Ponitria.

2 The article does not seek to create an inventory of all finds of the given type of ovens in the Nitra region. 